\title{
Effect of nursing care protocol on clinical outcomes of \\ Thalassemic children who receiving iron chelation therapy
}

Thanaa A. Mater: Master Degree of Pediatric Nursing,

Faculty of Nursing, Tanta University

Rahma Soliman Bahgat : Professor of pediatric Nursing

Faculty of Nursing, Tanta University

Mohmed Elshanshory :Professer of Pediatric Medicine

Faculty of Medicine, Tanta University

\begin{abstract}
Children with hemoglobin level less than $7 \mathrm{~g} / \mathrm{dl}$ require regular transfusions in the presence of growth impairment. The children need to take medications that rid the body of extra iron. Thalassemic children receiving desferal should be monitored for body weight and growth every 3 months. Protocol of care provided for thalassemic children on the chelation therapy is to achieve the optimal outcome in the treatment. Splenectomy is considered when a patient is more than five years old. The aim of this study; was to evaluate the effect of the nursing-care protocol on the clinical outcomes of thalassemic children who receive iron chelation therapy. This study was conducted at Pediatric Hematology and Oncology Unit of Tanta Main University Hospital. Materials and method, this study was conducted at Pediatric Hematology and Oncology Unit of Tanta Main University Hospital. All pediatric nurses (40) in the previously mentioned setting and assigned for providing care for thalassemic children. Thalassemic children who received the chelation therapy were collected randomly. Four tools were used of collect the data; a structured interview schedule, nurses' knowledge regarding thalassemic children, Nurses skills observation checklist and anthropometric measurements for thalassemic children. Results revealed that the mean age of the nurses There was a significant difference in nurses' knowledge about anemia and chelation therapy before and immediately after the nursing - care protocol More than half of the studied children were underweight while children's upper mid arm circumference was normal and more than half of the studied children and skin-fold thickness was normal the third of the studied children. It can be concluded that the application of the nursing-care protocol caused improvement in nurses' knowledge, practice and clinical outcomes of thalassemic children.
\end{abstract}

Key words: Nursing care protocol, clinical outcomes, thalassemic children, iron chelation therapy 


\section{Introduction}

Thalassemia is a pediatric inherited disease caused by genetic blood disorder. There is an absence or reduction in the production of hemoglobin. The erythrocytes are unable to carry adequate oxygen to the cells and tissue, leading to inadequate tissue perfusion, delayed growth and development with a usual life span of 20-30 years. The body is disabling to produce enough protein needed to form hemoglobin to carry oxygen throughout the body. Insufficient oxygen in bloodstream notices certain signs and symptoms like fatigue and other health problems. Children live full lives with careers and children of their own. ${ }^{(1,2)}$

World widely, there are 350,000 births per year with serious hemoglobinopathies. Increasing migration of population at risk to non-endemic countries has resulted in increasing prevalence of thalassemia gene mutations in all parts of the world. In developed countries, thalassemia trait forms a protection against malaria, where malaria is endemic. The severe form of the disease especially prevails in small countries where there are close family marriages. ${ }^{(3-5)}$

There are numerous types of thalassemia depending whether a person has defects in the alpha $(\alpha)$ or beta $(\beta)$ protein chains. Alpha thalassemia refers to a group of disorders characterized by inactivation of alpha globin genes. The production of $\alpha$ globin is deficient. $\beta$ thalassemia is the defective production of $\beta$ globin. The beta chains of the molecule of the hemoglobin are missing, resulting in deficient hemoglobin and the development of fragile, microcytic and hypochromic erythrocytes. ${ }^{(1,4)}$

Genes determines who will inherit thalassemia. The most common single gene disorder known as a silent carrier state causes no health problems and the hemoglobin functions normally. It is called a silent carrier because of how difficult it is to detect. A silent carrier state was diagnosed by deduction when an apparently normal individual has a child with hemoglobin $\mathrm{H}$ disease or alpha thalassemia trait. ${ }^{(4)}$

Diagnosis of thalassemia through laboratory screening for patients rule out other causes of anemia. Complete blood count, hemoglobin electrophoresis, fractions of hemoglobin and other variants are measured. Characteristic faces of thalassemia major are: The maxilla may overgrow with overbite and prominence of the upper incisors.Separation of the orbit 
ribs. Long and flat bones may be deformed. Enlarged heart, cardiac failure, hyperbilirubinemia, gallstones, gout, splenomegaly, liver endocrine, and hepatocellular carcinoma may happen. ${ }^{(5,6)}$ The most common complications of thalassemic children are cardiac, short stature, pubertal delay, and osteoporosis. Repeated transfusions increase the risk of blood-borne diseases including hepatitis B, $\mathrm{C}$ and blood-borne infections. Infection may cause pyrexia and enteritis in children with iron overload. Other less common complications include diabetes mellitus. Disturbed body image relates to alterations in the perceptions of self-due to actual or perceived alterations in body structure or function. Lack of condensation in one's self is characterized by negative selfstatements. Lack of concern about personal appearance and withdrawal from others are not related to physical problems or attributes. $^{(1,7)}$

The main problems of thalassemic children are in conduct, socialized aggression and anxiety withdrawal. The hematological parameters do not show significant predictive value in behavioral problems of thalassemic children. Some patients have a serious psychological aversion to take the medicine and may need professional counseling. It is imperative that patients with thalassemia understand their disease and treatment in order to follow their prescribed medical regiments. Child life programs in health-care settings minimize psychological trauma and promote optimal development of children and their families. ${ }^{(8)}$ With improved screening programs, better methods of measuring iron's impact, a safer blood supply and more drug treatment options, people with thalassemia are surviving until their fifth decade and beyond. The golden rule for survival is less iron is better and strict adherence to treatment is the most important predictor for survival. The aim of transfusion therapy is to permit normal growth and activity level, to prevent skeletal changes, and to maintain the pre-transfusion hemoglobin level between 9 and $10 \mathrm{~g} / \mathrm{dl}$. The amount of blood received on transfusion day is determined by pre-transfusion hemoglobin levels. ${ }^{(9,4,10)}$

Children who are being transfused every three or four weeks gain $0.5 \mathrm{mg} / \mathrm{kg}$ per day of iron in excess of natural losses. Children with a hemoglobin level less than $7 \mathrm{~g} / \mathrm{dl}$ require regular transfusions in the presence of growth impairment. Post-transfusion 
hemoglobin should be between 13.5 - 15.5 $\mathrm{g} / \mathrm{dl}$. Annual blood transfusion requirement in patients without hypersplenism is usually below $200 \mathrm{ml}$ packed red blood cells/kg per year. ${ }^{(1,10)}$

Dealing with iron overloaded from blood transfusions, from iron in the food eaten and from other issues related to the disease and its treatment has great importance. The children need to take medications that rid the body of extra iron. Children should start with a daily chelation therapy based on the total amount of blood transfused, ferritin levels, and degree of iron loading. Chelation therapy should start after about one year of chronic transfusions. Serum ferritin should be at least $3,000 \mu \mathrm{g} / \mathrm{g}$ dry weights before starting chelation regimen of chelation therapy ${ }^{(10,11)}$

There are three approved iron chelators: deferoxamine (Desferal), deferasirox (Exjade), and deferiprone (L1). Deferoxamine treatment is usually withheld until after two years of age because side effects of chelators in general are greater with limited iron stores and in children under two to three years of age. Adequate assessment of iron stores before the initiation of therapy is important. Treatment for seven days a week should be the goal.
Starting at a lower number of days per week and advancing to five to seven help the family adapt to and accept the new therapy. A small battery-operated pump, called an infusion pump, is used to get the drug into the body. Some patients who may use a balloon pump which comes with pre mixed are ready to use deferoxamine. ${ }^{(2,11)}$ Thalassemic children receiving desferal should be monitored for body weight and growth every 3 months. An increase in chelation is frequently necessary with an increase in blood requirement. A liver biopsy should be obtained before initiating treatment. Increasing length of survival has become an increasing problem. Desferrioxamine can cause toxicity. Local reaction at the site of injection can be severe. High-frequency hearing loss has reported in $30-40 \%$ of patients. Color and night blindness can be occurring. Deferoxamine manufactured in a powder form and mixed with sterile water is ready to be used. ${ }^{(1,11)}$

Splenectomy is considered when a child is more than five years old Increased transfusion requirements exceeding 200$250 \mathrm{ml} / \mathrm{kg} /$ year of pure red blood cells are evidence of hypersplenism and massive splenomegaly. ${ }^{(12)}$ 
The only cure for thalassemia is stem cell transplantation which is also called a bone marrow transplant which has better outcomes. It should be offered if there is a compatible sibling / family member. Bone marrow transplantation from unrelated and alternative donors, cored of blood transplantation and peripheral blood of stem cell transplantation services can be indicated. A cure means that genetic defect that causes the anemia has been corrected and that patient's body begins producing healthy blood cells. Transfusions and chelation therapy do not cure the condition. There are some curative approaches available: stem cell transplantation and gene therapy. ${ }^{(1,2)}$

The nurse plays an important role for the care of thalassemic children because the nurse helps in improving the quality of life and facilitating the child and family's adaptation to illness. Nursing care is the services rendered by the nurse for the benefit of the child using the protocol which is a detailed set of instructions to guide the care of a child or to assist the practitioner in performance of a procedure. $^{(13)}$

Thalassemia children should undergo at least an annual comprehensive assessment.
During such an assessment, recommendations are summarized and communicated directly. Monitoring chelation therapy to achieve optimal outcome in the treatment and Primary care are included. Monitoring of growth, general health and twenty-four hour backup consultation should be available. Clinical outcomes are broadly agreed such as measurable changes in health or quality of life that result from care. Constant review of clinical outcomes establishes standards which continuously improve all aspects of the practice. ${ }^{(14)}$

\section{The aim of this study was to:-}

Evaluate the effect of nursing-care protocol on the clinical outcomes of thalassemia children who receive iron chelation therapy.

\section{Setting:}

This study was conducted at Pediatric Hematology and Oncology Unit of Tanta Main University Hospital.

\section{Research Design:}

Quasi-experimental research design was used in this study.

\section{Subjects:}

1-All pediatric nurses (40) in the abovementioned setting were assigned for 
providing care for thalassemic children with different qualifications and length of experience.

2- Thalassemic children who received chelation therapy were randomly selected and had the following criteria:

- Age ranged from 6 to 18 years

- Free from any other chronic diseases except complications of thalassemia.

\section{Tools of data collection:}

\section{Four tools were used for collect the data.}

Tool I: a structured interview schedule:

It was designed and developed by the researcher and adopted from previous research references after reviewing related literature. It was done in Arabic form in order to prevent misunderstanding. The investigator interviewed the studied nurses and gave them the chance for asking any question. It included the following parts:

\section{A-Socio-demographic characteristics related to:}

a- The nurse such as age, qualifications, marital status, length of experience and residence.

b-The children such as age, sex, birth order, education and mother/father consanguinity.

c- Medical history of the disease which included: onset, diagnosis, types of treatment, places of investigation, blood transfusion, iron chelation therapy.

\section{d- Activities of the children's everyday} which included life sports, activities and complaint or suffering from any symptoms after doing any effort.

Tool II: Part (1): Nurses' knowledge regarding thalassemic children included

Definition of anemia and thalassemia, Component of blood, function and normal level of hemoglobin.

Normal level of serum ferritin in the blood, how does regular blood transfusion lead to iron overload, iron-containing diet factors preventing iron absorption, factors increasing iron absorption and effect of iron overload on different body organs.

Measures for dealing with thalassemic children., New trends for early detection.

Part (2): Nurses' knowledge about the therapy of iron chelation included: importance, types, and forms, methods of administration, side effects and precautions that were already taken to avoid complications.

The nurses were asked to respond to these questions with the correct response for each question .Evaluation of thalassemic children, clinical outcomes and findings were compared with normal results 


\section{The scoring system:}

The interview sheet contained multiple choices and was revised by a pediatric nursing experts .The nurses were instructed to choose one or more correct answer / answers from choices of each question. Assessment of nurses' knowledge of the chelation therapy was as follows:

The total score of the nurses' knowledge equals $100 \%$ and accordingly the nurses' answer were classified as follows:

- Correct and complete answers were scored (2)

- Correct and incomplete answers were scored (1).

- Wrong or incorrect answers and didn't know answers were scored (0)

Total scores of total nurses' knowledge were calculated and classified as follows:

- Poor score of knowledge (Less than 60\%)

- Fair score of knowledge (60\% - $69 \%$ )

- Good score of knowledge (70-100\%)

The researcher assessed the nurses' knowledge of thalassemic children three times:

1) Before sessions.

2) Follow up immediately after sessions.

3) Follow up three months after sessions.

Tool III: Nurses' skills of observation checklist: the researcher developed this tool after reviewing the related literature. It was used to assess nurses' clinical performance during:

a- Administration of deferoxamine (Desferal) subcutaneously by using infusion pump.

b- Administration of blood transfusion.

\section{The scoring system:}

The observation sheet containing steps of the procedures was revised and observed by a pediatric nursing expert . The nurses were observed during the procedures without any comment. Assessment of nurses' practice of chelation therapy and blood transfusion was as follows:

The total score of the nurses' practice equals $100 \%$ and accordingly the nurses' administration was classified:

Nurses' performance of chelation therapy and blood transfusion was as follows:

-Done correctly was scored 1

-Incorrect or not done was scored Zero

The total score of the nurses ' performance equals $100 \%$. Total scores of nurses' performance were calculated and accordingly classified follows:

- Poor performance (Less than 60\%)

- Fair performance (60\% - $69 \%)$

- Good performance (70 - 100\%) 
The researcher assessed the nurse's performance regarding desferal administration subcutaneously, using minipump and blood transfusion administration to thalassemic children three times:

1) Before the sessions.

2) Follow up immediate after sessions.

3) Follow up three months after sessions.

Tool IV: Anthropometric measurements for thalassemic children: weight, height, upper mid arm circumference, skin-foldedthickness and body mass index were measured and calculated. Each of these measurements was taken according to the standard procedure recommended by Jelliffe. (15) The improvement or at least stability of anthropometric measurements indicates the effectiveness of the sessions.

Clinical outcomes of thalassemic children; the findings were compared to normal results.

\section{The scoring system:}

The anthropometric measurements and steps of the procedures were revised through related literature. Nurses provided Helping and cooperation. Assessment of anthropometric measurements was as follows: (Weight, height, upper mid arm circumference, skin-fold thickness and body mass index). Each one was taken according to standard and compared with normal standard of corresponding Egyptian for age and sex.

1-Weight / age (was measured using a bathometer scale and recorded to the nearest tenth of a kilogram) and was used as an indicator of the nutritional state for the children classified as follows:

- Children having less than $90 \%$ of the standard weight / age were considered underweight.

- Children having 90-110\% of the standard were considered normal.

- Children having over $110 \%$ of the standard were considered overweight. (WHO 1987)(16)

2- Height / age (was measured using the stadiometer scale and was taken to the nearest $0.1 \mathrm{~cm}$ and then recorded) and was used as follows:

- Children having less than $90 \%$ of the standard height were considered stunted.

- Children having $90 \%$ - $110 \%$ of the standard height were considered normal.

- Children having over $110 \%$ of the standard height were considered tall. (WHO1987)(16)

3- Upper mid arm circumference was measured by letting the child's right arm 
be flexed $90^{\circ}$ at the elbow, marking the midpoint between the acromion and the olecranon on the posterior aspect of the arm and wrap a paper or steel measuring tape around upper arm at midpoint . The measurement was recorded to the nearest $0.1 \mathrm{~cm}$.

4- Skin-fold thickness: Skin - fold thickness of triceps was measured using the Harpenden skinfold caliper. Let the child's right arm flex 90 at the elbow, marking the midpoint between the acromion and the olecranon on the posterior aspect of the arm. Let the child's arm hang freely and grasp a fold of skin between the thumb and forefinger about $1 \mathrm{~cm}$ above the midpoint. Gently pull a skin fold away from the underlying muscle, continue to hold the skin until the measurement is completed, place the caliper jaws over the skin-fold at the midpoint mark, estimate the reading to the nearest 1.0 $\mathrm{mm}, 2$ to 3 seconds after applying pressure and read measurements until duplicates agree within $1 \mathrm{~mm}$.

- Children less than $80 \%$ of the standard were considered under normal.

- Children having 80 - $110 \%$ of the standard were considered normal.
- Children having over $110 \%$ of the standard were considered above normal.

5- Body Mass Index: Accurate height and weight were required for calculation of BMI. It is calculated the same way as for adults (BMI=weight $(\mathrm{Kg}) /$ height $^{2}(\mathrm{~m})^{2}$, but then compared to typical values for children of the same age. The BMI percentile allows the nurse to compare between children of the same sex and age. ${ }^{(16,17)}$ 


\section{Tanta Scientific Nursing Journal}

\begin{tabular}{|l|l|}
\hline Category & BMI (children 2- 20 ) \\
\hline Under weight & BMI for age and sex 5\% \\
\hline Normal weight & BMI for age and sex $\geq 5$ to $\leq 85 \%$ \\
\hline Risk for overweight & BMI for age and sex $\geq 85$ to $\leq 95 \%$ \\
\hline Overweight & BMI for age and sex $\geq 95 \%$ \\
\hline
\end{tabular}

\section{Method}

\section{1- Administrative process:}

Such a study was carried out after getting an official permission from the responsible authorities and administrative staff of hospital department to carry out the study after the explanation of the aim of the study.

Oral consent was obtained from the nurses for agreement to participate in the present study after explanation of the study purpose.

Each nurse was individually interviewed to collect necessary data of tool I and tool II. The time consumed to each interview sheet ranged from 30-40 minutes.

Each nurse was observed during using tool III (A). The time consumed to observe each nurse ranged from 15-20 minutes for desferal administration subcutaneously by using infusion pump.

Each nurse was observed using during tool III (b). Time consumed to observe each nurse ranged from 2-3 hours for blood transfusion.
2-Ethical consideration: Participants, oral consent was obtained and purpose of the study was explained to them. Each subject informed about the confidentiality and his or her right to withdraw at any time without any compensations. Participants' privacy was considered.

\section{3- A Pilot Study: pretest of the used tools} was carried out on (10\% of nurses). It was done before starting the data collection to verify the applicability, feasibility and clarity of the tools. The results of the pilot study were used to finalize the tools and to schedule the fieldwork, to estimate and to determine the time required to complete data collection.

Those who shared in the pilot study were excluded from the study sample.

\section{4- Tool development:}

Four tools were used in this study:

Tool (I): The researcher had an interview with the expert group to elicit their opinions regarding the expected competence (knowledge and skills) about the effect of the protocol on clinical 
outcomes of thalassemic children who receive iron chelation therapy.

Tool (II): It was used by the researcher to compare the actual nurses, knowledge regarding thalassemic children with the ideal knowledge mentioned in literature review section.

Tool (III): It was used by the researcher to assess the nurses' competence (knowledge and skills) of administration of desferoxamine (Desferal) subcutaneously by using infusion pump and administration of blood transfusion.

Tool (IV): It was used by the researcher to assess the anthropometric measurements: weight, height, upper mid arm circumference, skin-fold thickness and body mass index were which all measured, calculated and compared with the standardized.

Validity of the tools: The tools of such a study were tested for content validity by three experts of the jury in the field of Pediatric Nursing and Pediatrics. Modifications were carried out accordingly. 5-Nursing care protocol: It was based on the results obtained from the assessment by using the interview schedule of observation checklist as well as literature review aiming to satisfy the studied nurse's deficient knowledge and practice about management of thalassemic children. The nursing care protocol included different sessions developed by the researcher for improving nurses' practice and knowledge for caring of children with thalassemia. Health instructions were developed and implemented through four phases:

Assessment phase: The basic competence and its underlined activities regarding the effect of the nursing care protocol on clinical outcomes of thalassemic children who receiving iron chelation therapy were done by reviewing the related literature.

- The researcher had an interview with the experts group using tool (I) explanation of the aim of the study to elicit their opinions regarding the expected competence (knowledge and skills) on the effect of the nursing care protocol on clinical outcomes of thalassemic children who receiving the iron chelation therapy. Any item in this study questionnaire- structured agreed by $60 \%$ of the expert group was included in the standards. Specialists in the field of working with thalassemic children considered as essential.

\section{Planning phase:}

It was based on the results of a questionnaire, the observational checklist 
reviewing the most recent related literature, the learning needs were identified, and the nursing care protocol was developed. The preparation of suitable media for teaching was chosen.

\section{Implementation phase:}

The nursing care protocol was carried out in the lecture room in Hematology and Oncology Unit and Outpatient Clinic according to the nurses' workplace. The program was 8 sessions. The action plan was done through a structured interview with the nurses. The suitable media for teaching nurses such as lectures, videos, power point presentations, discussions, demonstrations, simulations and posters used during the nursing care protocol presentation according to the content of the session. Studied nurses were divided into subgroups. The number of each group was 10- 15 nurses. The duration of each session will be from 45 - 90 minutes, including periods of re-demonstration and discussion.

The first session: At the beginning of the initial interview, an orientation to the nursing care protocol and its objectives took place. This session included informing nurses about definition of blood, function of blood, Blood composition, anemia, normal hemoglobin level in children (male and female), the most common blood diseases especially hereditary example and how can hereditary blood diseases be transmitted and prevented.

The second session: It began with a review of concepts previously presented in the first session and progressed to the next level which focused on: definition, types, manifestations, complications, prevention of thalassemia, methods for investigations, effect of regular blood transfusion on increasing the iron level, importance of hemoglobin and iron follow up.

The third session: It focused on; normal iron level and its importance, causes of iron overload, manifestations of iron overload, complications of iron overload, method of iron precipitation and prevention of iron overload.

The fourth session: It concentrated on iron chelation therapy especially Desferoxamine (Desferal), its importance; forms; route of administration and infection control measures. Desferal was administrated subcutaneously by using infusion mini pump properly. Prevention of the complications of the therapy through: selection of suitable site of injection, follow proper nursing care during the procedure, good observation for both actual and 
potential complications with measures for overcome or dealing with was important. Exjate another chelator, was taken orally, blood transfusion purpose of transfusion, and steps of procedure.

The fifth session: It focused on administration of blood transfusion: The blood keeping, carful donor selection ,ABO grouping, $\mathrm{RH}$ typing, cross matching, test of laboratory screening, blood irradiation, blood worming, the preferred sits for administration for children, measures of infection control, related to blood transfusion and most common complications to avoid or deal with .

The sixth session: It centered on spleen; importance, indications of splenectomy, causes of splenectomy, suitable age of spleen removal, care of splenectomized thalassemic child including kindly explanation and emotional support to the child and the caregiver .

The seventh session: It was aimed to achieve good lifestyle through; modifications of the life-style profile to be compatible to the disease condition which would provide lifestyle as normal as possible such as diet, activity, exercise and recreation.
The eighth session: It began with summarizing the main items in the previous sessions. Concentrating on prevention and early detection of the disease: Health Instructions about premarital genetic counseling, new trends for early detection, prevention and proper management of the disease.

\section{Evaluation phase:}

After the implementation of the guidelines, the post- test was done to the studied nurses' knowledge and practice by the same format of the pre-test, using a tool to evaluate the effect of the implemented guidelines on the nurses immediately and three months after the nursing care protocol.

\section{Clinical outcomes of thalassemic children:}

- According to the nursing care protocol, there was improvement of the nurses' knowledge regarding thalassemic children that had the impact on changing the children's lifestyle.

- The knowledge given to thalassemic children's nurses was applied and better lifestyle was achieved.

- Thalassemic nurses observed during administration of; blood transfusion, 
administration of desferal using desferal pump and measuring anthropometric measurements (weight, height, upper mid arm circumference and skinfold thickness ) of thalassemic children.

- Nurses care protocol-decreased children's need for blood transfusion, desferal therapy and the complications of administration. Improvement of the children' anthropometric measurements and body mass index 3 months after the nursing-care protocol than before or immediately after the nursing care protocol was noticed .

\section{Data collection:}

The researcher collected data by using interview questionnaires. Data were collected over a period of 7 months starting from $1^{\text {st }}$ August 2014 to $1^{\text {St }}$ March 2015. Appointment was taken according to morning shift schedule, working days and availability of nurses.

\section{Statistical analysis:}

The collected data were organized, tabulated and statistically analyzed using SPSS. Version 17 for qualitative variable mean and standard deviation were calculated. The value of $<0.05$ indicates a significant result. Analysis of the presentation study was done, using the mean, standard error, student t-test, paired t-test, Chi-square, coefficient of Linear Correlation and Analysis of variance.

\section{Results:}

Table (1) showed the percentage of the distribution of the studied nurses regarding their socio- demographic characteristics. It was observed that nurses whose age between 30- 40 years were more than three quarters of the sample $(82.5 \%)$, with the mean age of $35.71 \pm 18.22$ years. Nineteen percent of the studied nurses have secondary education only (3 years) compared to $5 \%$ who have secondary school (Diploma and specialty) or faculty of nursing. More than a half of the studied nurses $(55 \%)$ were married while $45 \%$ were single. Most of studied nurses (85\%) have 10-20 years of experience. Regarding the residence, it was clear that the majority of studied nurses (87.5\%) live in rural areas.

Table (2) presented the distribution of the studied children according to their characteristics. It was observed that about one-third $(37.5 \%)$ of the studied children were aged $\geq 6$ and (42.5\%) were aged $9<$ 12 with a mean age $9.48 \pm 4.89$ years. Regarding sex, it was observed that slightly less than two thirds $(60 \%)$ of the studied children were males while about more than 
one third $(40 \%)$ of them were female. It was found that $47.5 \%$ of the studied children were the second in birth order compared to $5 \%$ who were $5^{\text {th }}$ in order. This table also illustrates that $5 \%$ of children are illiterate or just read and write. The education for the studied children was (82\%, 10\%, and $2.5 \%)$ for primary, preparatory, secondary education respectively. It was noticed that positive parent's consanguinity revealed in more than a half of the studied children $(60 \%)$.

Table (3) illustrated the percentage of the distribution of the studied nurses' knowledge about thalassemic children. Regarding signs and symptoms of thalassemia, it a was satisfactory significant difference $(\mathrm{P}=0.000, \mathrm{P}=0.004$ and $\mathrm{P}=$ 0.000 ) of the studied nurses' knowledge before, immediately after and 3 months after the nursing-care protocol respectively. There was a significant difference in the nurses' knowledge about anemia, early diagnosis, causes, pathophysiology, complications, prevention and dealing with thalassemia $(\mathrm{P}=0.001, \mathrm{P}=0.036, \mathrm{P}=0.000$, $\mathrm{P}=0.002, \mathrm{P}=0.001, \mathrm{p}=0.000, \mathrm{P}=0.000$ and $\mathrm{P}=0.000$ respectively) before and immediately after the nursing-care protocol. No significant difference for the studied nurses' knowledge in relation to mode of thalassemia transmission $(\mathrm{P}=$ $0.056, \mathrm{p}=0.606$ and $\mathrm{P}=0.160$ respectively) before, immediately after and 3 months after the nursing-care protocol.

Table (4) portrayed the percent of the distribution of the studied nurses' knowledge regarding iron and iron chelation therapy. As regard to questions about iron level, function iron-chelation therapy forms of chelation therapy, affection of body organs by iron precipitation, common types of desferal, frequency of desferal weekly and its preferred sits, the studied nurses' answers were of significant difference $(\mathrm{P}=0.000$, $\mathrm{P}=0.000, \quad \mathrm{P}=0.002, \quad \mathrm{P}=0.013, \quad \mathrm{P}=0.035$. $\mathrm{P}=0.003, \mathrm{P}=0.04$ respectively) before and immediately after the nursing-care protocol. Regarding the studied Nurses' knowledge about the frequency of desferal which the child needs weekly it was of insignificant difference before and immediate after the nursing-care protocol.

Table (5) revealed the percentage of the distribution of the studied nurses' knowledge regarding desferal. The result illustrated that there was a statistical significant difference in nurses' knowledge regarding indications, side effects, 
precautions and complications of desferal $(\mathrm{P}=0.034, \quad \mathrm{P}=0.000, \quad$ and $\quad \mathrm{P}=0.000$ respectively) before and immediately after the nursing-care protocol. No significant difference was present immediately after and 3 months after the nursing care protocol.

Table (6) represented the percentage of the distribution of the nurses' knowledge regarding blood and blood transfusion. There were satisfactory significant differences in studied nurses' knowledge related to components of blood, function of blood, normal child's hemoglobin level, effect of blood transfusion, indications for transfusion, benefits of blood transfusion, complications and body responses to complications of blood transfusion ( $\mathrm{P}=0.000, \quad \mathrm{P}=0.001, \quad \mathrm{P}=0.000, \quad \mathrm{P}=0.001$, $\mathrm{P}=0.000, \mathrm{P}=0.001, \mathrm{P}=0.006$ and $\mathrm{P}=0.000$ respectively) before and immediately after the nursing-care protocol. On the other hand, there were no significant differences related to the nurses' knowledge regarding components of blood, function of blood, effect of blood transfusion, and indications for transfusion, complications and body responses to complications of blood transfusion $(\mathrm{P}=0.152, \mathrm{P}=0.152, \mathrm{P}=0.152$, $\mathrm{P}=0.785, \mathrm{P}=0.152$, and 0.115 respectively) immediately after and 3 months after the nursing-care protocol.

Table (7) illustrated percentage distribution of studied nurses' knowledge regarding nutrition of thalassemic children. It was found that $(62.5 \%, 92.5 \%$ and $95 \%$ respectively) of studied nurses mentioned correct and complete knowledge about types of foods rich in iron before, immediately after and 3 months after the nursing-care protocol prospectively. There was a significant relation regarding the knowledge about types of foods rich in iron before and 3 months after the nursing-care protocol $(\mathrm{P}=0.001)$. Foods or drinks which decrease the absorption of iron were stated correctly and completely by $(2.5 \%, 92.5 \%$ and $85 \%$ respectively) of studied nurses before, immediately after and 3 months after the nursing-care protocol. There was a significant relation regarding the knowledge about types of foods which decrease the iron absorption before and after the nursing-care protocol $(\mathrm{P}=0.000)$. Foods or drinks which increase the absorption of iron were stated by $(85 \%$, $7.5 \%$ and $17.5 \%$ respectively) of the studied nurses before, immediately after and 3 months after the nursing-care protocol. There was a significant relation 
regarding knowledge about types of foods which increase the iron absorption before and after the nursing-care protocol $(\mathrm{P}=0.009)$.

Table (8) revealed the percentage of the distribution of studied nurses' knowledge regarding laboratory investigations of thalassemic children. The table illustrated that (85\%, 95\% and $87.5 \%$ respectively) of the studied nurses mentioned new trends for investigations correct and complete. There was no significant relation regarding knowledge about new trends for investigations before and after the nursingcare protocol $(\mathrm{P}=0.745)$. As regards the importance of premarital counseling, most ( $90 \%$ and $100 \%$ respectively) of studied nurses mentioned that the premarital counseling was impotent before and after the nursing-care protocol. There was a significant relation regarding the knowledge about the importance of premarital counseling before and after the nursing-care protocol $(\mathrm{P}=0.04)$. The table showed that $(55 \%, 100 \%$ and $95 \%)$ of studied nurses' knowledge about blood analysis of iron level was correct and complete before, immediately after and 3 months after the nursing-care protocol. There was a significant relation regarding the knowledge of blood analysis of iron level before and after the nursing-care protocol $(\mathrm{P}=0.000)$.

Table (9) represented the distribution of the studied children regarding the percent of the standard of their anthropometric measurements. As regards the percent the standard weight for age and sex, this table showed that $62.2 \%$ of the studied children were underweight (less than $90 \%$ of their standard weight for age and sex) and 5\% were overweight (over $110 \%$ of the standard weight for age and sex).This distribution changed after the nursing-care protocol where the percent of the underweight children dropped to $35 \% 3$ months after the nursing care protocol and that of the overweight of studied children to $5 \%$. Those which changed were a statistically significant difference.

Regarding the percent of the standard height for age and sex, this table showed that $62.2 \%$ of the studied children were short stature (less than 90\% of their standard height for age and sex) and 15\% were normal $(90 \%-110 \%$ of the standard height for age and sex).This distribution changed after the nursing-care protocol where the percent of the short stature of the studied children dropped to $55 \% 3$ months 
after the nursing-care protocol and that of the normal height of studied children reached $45 \%$. Those changed which were a statistically significant difference.

In relation to the percent of the standard of the upper mid arm circumference for age and sex, this table showed that $62.2 \%$ of studied children were less normal (less than $90 \%$ of the standard of the upper mid arm circumference for age and sex) and 5\% were above normal (over $110 \%$ of the standard upper mid arm circumference for age and sex).This distribution changed after the nursing-care protocol where the percent of the less normal children dropped to $50 \%$ 3 months after the nursing-care protocol and that of the above normal children reached $2.5 \%$. Those which changed were a statistically significant difference.

The table showed also the percent of the standard of the skin-fold thickness for age and sex. This table presented that $65 \%$ of studied children were less normal (less than $80 \%$ of the standard of their skin fold thickness for age and sex) and 5\% were above normal (over $110 \%$ of the standard of the upper mid arm circumference for age and sex).This distribution changed after the nursing-care protocol where the percent of the less normal children dropped to $45 \% 3$ months after the nursing-care protocol and that of the above normal children reached $2.5 \%$. Those which changed were a statistically significant difference.

Table (10) represented the distribution of the studied children regarding their body mass index. It was noticed that $(65 \%$ and $37.5 \%$ respectively) of studied children were under weight $(<18.5)$ before and 3 months after the nursing-care protocol, statistically $\mathrm{P}=(0.653)$. 
Table (1): The percentage of the Distribution of Studied Nurses Regarding Their Socio-

Demographic Characteristics

\begin{tabular}{|c|c|c|}
\hline Socio-demographic of Studied Nurses & $\begin{array}{c}(n o=40) \\
\text { No }\end{array}$ & $\%$ \\
\hline \multicolumn{3}{|l|}{ Age (years) } \\
\hline$\leq 20$ & 3 & 7.5 \\
\hline $30<40$ & 33 & 82.5 \\
\hline-40 & 4 & 10 \\
\hline Mean \pm SD & \multicolumn{2}{|c|}{$35.71 \pm 18.22$} \\
\hline \multicolumn{3}{|l|}{ Educational level } \\
\hline Secondary school (3 years) & 36 & 90 \\
\hline Secondary school (Diploma and specialty) & 2 & 5 \\
\hline Faculty of nursing & 2 & 5 \\
\hline \multicolumn{3}{|l|}{ Marital status } \\
\hline Single & 18 & 45 \\
\hline Married & 22 & 55 \\
\hline \multicolumn{3}{|l|}{ Number of experience years } \\
\hline Less than 10 & 1 & 2.5 \\
\hline-10 & 34 & 85 \\
\hline-20 & 5 & 12.5 \\
\hline \multicolumn{3}{|l|}{ Residence } \\
\hline Urban & 5 & 12.5 \\
\hline Rural & 35 & 87.5 \\
\hline
\end{tabular}


Table (2): The percentage of the Distribution of Studied Children Regarding their Characteristics

\begin{tabular}{|l|l|l|}
\hline \multicolumn{1}{|c|}{ Characteristics of Studied Children } & \multicolumn{1}{c|}{$\begin{array}{c}\text { no }=\text { 40) } \\
\text { No }\end{array}$} & \% \\
\hline Age (years) & 15 & 37.5 \\
\hline$\geq 6$ & 17 & 42.5 \\
\hline $9<12$ & 8 & 20 \\
\hline$\geq 12$ & $\mathbf{9 . 4 8} \pm \mathbf{4 . 8 9}$ \\
\hline Mean \pm SD & \multicolumn{2}{|l|}{} \\
\hline Sex & 24 & 60 \\
\hline Male & 16 & 40 \\
\hline Female & \multicolumn{2}{|l|}{} \\
\hline Family order & 19 & 47.5 \\
\hline First & 14 & 35 \\
\hline Second & 4 & 10 \\
\hline Third & 1 & 2.5 \\
\hline Fourth & 2 & 5 \\
\hline Fifth & \multicolumn{2}{|l}{} \\
\hline \hline Educational level & 2 & 5 \\
\hline \hline Read and write or illiterate & 33 & 82.50 \\
\hline Primary education & 4 & 10 \\
\hline Preparatory education & 1 & 2.50 \\
\hline Secondary education & 16 & 60 \\
\hline Parents' consanguinity & 24 & 40 \\
\hline Positive & \multicolumn{2}{|l|}{} \\
\hline Negative & \multicolumn{2}{|l|}{} \\
\hline
\end{tabular}




\section{Table (3): The percentage of the Distribution of the Studied Nurses' Knowledge Regarding Thalassemic Children}

\begin{tabular}{|c|c|c|c|c|c|c|c|c|c|c|c|c|c|c|c|c|c|c|c|c|c|}
\hline \multirow{3}{*}{ Nurses' Knowledge } & \multicolumn{6}{|c|}{$\begin{array}{l}\text { Before the Nursing Care Protocol } \\
(\text { no }=40)\end{array}$} & \multicolumn{6}{|c|}{$\begin{array}{l}\text { Immediately After the Nursing Care Protocol } \\
\qquad\left(\mathrm{no}^{2} \mathbf{4 0 )}\right.\end{array}$} & \multicolumn{6}{|c|}{$\begin{array}{l}3 \text { Months After the Nursing Care Protocol } \\
\qquad(\mathrm{no}=40)\end{array}$} & \multirow{3}{*}{$\underset{\mathbf{p}-\text {-value }}{\chi^{2}}$} & \multirow{3}{*}{$\begin{array}{c}\chi^{2} \\
\text { p-value }\end{array}$} & \multirow{3}{*}{$\underset{\text { p-value }}{\chi^{2}}$} \\
\hline & \multicolumn{2}{|c|}{$\begin{array}{l}\text { Incorrect or } \\
\text { Don't know }\end{array}$} & \multicolumn{2}{|c|}{$\begin{array}{c}\text { Correct \& } \\
\text { Incomplete }\end{array}$} & \multicolumn{2}{|c|}{$\begin{array}{c}\text { Correct \& } \\
\text { Complete }\end{array}$} & \multicolumn{2}{|c|}{$\begin{array}{l}\text { Incorrect or } \\
\text { Don't know }\end{array}$} & \multicolumn{2}{|c|}{$\begin{array}{c}\text { Correct \& } \\
\text { incomplete }\end{array}$} & \multicolumn{2}{|c|}{$\begin{array}{r}\text { Correct \& } \\
\text { Complete }\end{array}$} & \multicolumn{2}{|c|}{$\begin{array}{l}\text { Incorrect or } \\
\text { Don't know }\end{array}$} & \multicolumn{2}{|c|}{$\begin{array}{c}\text { Correct \& } \\
\text { Incomplete }\end{array}$} & \multicolumn{2}{|c|}{$\begin{array}{r}\text { Correct \& } \\
\text { Complete }\end{array}$} & & & \\
\hline & No & $\%$ & No & $\%$ & No & \% & No & $\%$ & No & $\%$ & No & $\%$ & No & $\%$ & No & $\%$ & No & $\%$ & & & \\
\hline Definition of Anemia & 9 & 22.5 & 3 & 7.5 & 28 & 70 & $\mathbf{0}$ & $\mathbf{0}$ & 0 & $\mathbf{0}$ & 40 & 100 & 2 & 5 & $\mathbf{0}$ & $\mathbf{0}$ & 38 & 95 & $\begin{array}{l}* 14.118 \\
\left(0.001^{*}\right)\end{array}$ & $\begin{array}{r}* * 2.051 \\
(\mathbf{0 . 1 5 2})\end{array}$ & $* * * 8.970\left(0.011^{\#}\right)$ \\
\hline Definition of Thalassemia & 9 & 22.5 & 4 & 10 & 29 & 72.5 & 4 & 10 & 0 & $\mathbf{0}$ & 36 & 90 & 4 & 10 & 2 & 5 & 34 & 85 & $\begin{array}{c}* 6.632 \\
(0.036 *) \\
\end{array}$ & $\begin{array}{r}* * 2.057 \\
(\mathbf{0 . 3 5 8}) \\
\end{array}$ & $* * * 2.940(0.230)$ \\
\hline $\begin{array}{l}\text { Measures for Early Diagnosis } \\
\text { of Thalassemia }\end{array}$ & $\mathbf{0}$ & $\mathbf{0}$ & 14 & 35 & 28 & 70 & $\mathbf{0}$ & $\mathbf{0}$ & 0 & $\mathbf{0}$ & 40 & 100 & $\mathbf{0}$ & $\mathbf{0}$ & 1 & 2.5 & 39 & $\begin{array}{l}97 . \\
5\end{array}$ & $\begin{array}{l}* 16.078 \\
\left(0.000^{\# \#}\right)\end{array}$ & $\begin{array}{l}* * 1.013 \\
(0.314)\end{array}$ & $\begin{array}{l}* * * * 13.032 \\
\left(0.000^{* * t}\right)\end{array}$ \\
\hline Causes of Thalassemia & 12 & 30 & $\mathbf{0}$ & $\mathbf{0}$ & 28 & 70 & $\mathbf{0}$ & $\mathbf{0}$ & 0 & $\mathbf{0}$ & 40 & 100 & 2 & 5 & $\mathbf{0}$ & $\mathbf{0}$ & 38 & 95 & $\begin{array}{l}* 9.217 \\
(0.002 *)\end{array}$ & $\begin{aligned} * * 1.856 \\
(0.173)\end{aligned}$ & $\begin{array}{l}{ }^{* * * 13} 13.473 \\
\left(0.000^{* *}\right)\end{array}$ \\
\hline $\begin{array}{l}\text { Pathophysiology of } \\
\text { Thalassemia }\end{array}$ & 12 & 30 & $\mathbf{0}$ & $\mathbf{0}$ & 28 & 70 & 1 & 2.5 & 0 & $\mathbf{0}$ & 39 & 97.5 & 2 & 5 & $\mathbf{0}$ & $\mathbf{0}$ & 38 & 95 & $\begin{array}{l}* 11.114 \\
\left(0.001^{*}\right)\end{array}$ & $\begin{array}{c}* * 0.346 \\
(0.556)\end{array}$ & ****8.658 $\left(0.003^{*}\right)$ \\
\hline $\begin{array}{l}\text { Signs and Symptoms of } \\
\text { Thalassemia }\end{array}$ & $\mathbf{0}$ & $\mathbf{0}$ & 33 & 82.5 & 7 & 17.5 & $\mathbf{0}$ & $\mathbf{0}$ & 4 & 10 & 36 & 90 & $\mathbf{0}$ & $\mathbf{0}$ & 15 & 37.5 & 25 & 62. & $\begin{array}{l}* 42.288 \\
\left(0.000^{\# \#}\right)\end{array}$ & $\begin{array}{l}* * 8.352 \\
\left(0.004^{*}\right)\end{array}$ & $\begin{array}{l}* * * 6.875 \\
\left(0.000^{\# *}\right)\end{array}$ \\
\hline Complications of Thalassemia & 0 & $\mathbf{0}$ & 28 & 70 & 12 & 30 & $\mathbf{0}$ & $\mathbf{0}$ & 1 & 2.5 & 39 & 97.5 & $\mathbf{0}$ & $\mathbf{0}$ & 5 & 12.5 & 35 & $\begin{array}{c}87 . \\
5\end{array}$ & $\begin{array}{l}* 39.342 \\
\left(0.000^{\# \#}\right)\end{array}$ & $\begin{array}{c}* * 2.883 \\
(\mathbf{0 . 0 9 0 )}\end{array}$ & $* * * 27.286\left(0.000^{\# \#)}\right.$ \\
\hline $\begin{array}{l}\text { Mode of Thalassemia } \\
\text { Transmission }\end{array}$ & 17 & 42.5 & $\mathbf{0}$ & $\mathbf{0}$ & 23 & 57.5 & 9 & 22.5 & 0 & $\mathbf{0}$ & 31 & 77.5 & 11 & $\begin{array}{c}27 . \\
5\end{array}$ & $\mathbf{0}$ & $\mathbf{0}$ & 29 & $\begin{array}{c}72 . \\
5\end{array}$ & $\begin{array}{r}* 3.647 \\
(\mathbf{0 . 0 5 6 )} \\
\end{array}$ & $\begin{array}{r}* * 0.267 \\
(0.606)\end{array}$ & $\begin{array}{c}* * * * 1.978 \\
(0.160)\end{array}$ \\
\hline $\begin{array}{l}\text { Methods for Thalassemia } \\
\text { Prevention }\end{array}$ & 10 & 25 & 25 & 62.5 & 5 & 12.5 & $\mathbf{0}$ & $\mathbf{0}$ & 2 & 5 & 38 & 95 & 0 & 0 & 7 & 12.5 & 33 & $\begin{array}{r}82 . \\
5 \\
\end{array}$ & $\begin{array}{l}* 54.918 \\
\left(0.000^{\# \prime}\right)\end{array}$ & $\begin{array}{l}* * 3.130 \\
(0.077) \\
\end{array}$ & $* * * 40.77\left(0.000^{\# \#}\right)$ \\
\hline $\begin{array}{l}\text { Measures Used for Dealing } \\
\text { with the Thalassemic Child }\end{array}$ & $\mathbf{0}$ & $\mathbf{0}$ & 28 & 70 & 12 & 30 & $\mathbf{0}$ & $\mathbf{0}$ & 8 & 20 & 32 & 80 & $\mathbf{0}$ & $\mathbf{0}$ & 10 & 25 & 30 & 75 & $\begin{array}{l}{ }^{* 20.202} \\
\left(0.000^{\# \prime \prime}\right)\end{array}$ & $\begin{array}{l}* * 0.287 \\
(0.592)\end{array}$ & $\begin{aligned} * * * 16.218 \\
\left(0.000^{\# \#}\right)\end{aligned}$ \\
\hline
\end{tabular}

\section{${ }^{\#}$ Significant at level $\mathbf{P}<0.05$}

* Before the nursing care protocol and after the nursing care protocol

**Immediately after the nursing care protocol and 3 months after the nursing care protocol

*** Before the nursing care protocol and 3 months after the nursing care protocol 
Table (4): The percentage of the Distribution of the Studied Nurses' Knowledge Regarding Iron and Iron Chelation Therapy

\begin{tabular}{|c|c|c|c|c|c|c|c|c|c|c|c|c|c|c|c|c|c|c|c|c|c|}
\hline \multirow{3}{*}{ Nurses' Knowledge } & \multicolumn{6}{|c|}{$\begin{array}{l}\text { Before the Nursing Care Protocol } \\
\qquad(\mathrm{no}=40)\end{array}$} & \multicolumn{6}{|c|}{$\begin{array}{l}\text { Immediately After the Nursing Care Protocol } \\
\qquad(\mathrm{no}=40)\end{array}$} & \multicolumn{6}{|c|}{3 Months After the Nursing Care Protocol $(n o=40)$} & \multirow{3}{*}{$\underset{\text { p-value }}{\chi^{2}}$} & \multirow{3}{*}{$\begin{array}{c}\chi^{2} \\
\text { p-value }\end{array}$} & \multirow{3}{*}{$\begin{array}{c}\chi^{2} \\
\text { p-value }\end{array}$} \\
\hline & \multicolumn{2}{|c|}{$\begin{array}{l}\text { Incorrect or } \\
\text { Don't know }\end{array}$} & \multicolumn{2}{|c|}{$\begin{array}{c}\text { Correct \& } \\
\text { Incomplete }\end{array}$} & \multicolumn{2}{|c|}{$\begin{array}{l}\text { Correct \& } \\
\text { Complete }\end{array}$} & \multicolumn{2}{|c|}{$\begin{array}{l}\text { Incorrect or } \\
\text { Don't know }\end{array}$} & \multicolumn{2}{|c|}{$\begin{array}{l}\text { Correct \& } \\
\text { Incomplete }\end{array}$} & \multicolumn{2}{|c|}{$\begin{array}{l}\text { Correct \& } \\
\text { Complete }\end{array}$} & \multicolumn{2}{|c|}{$\begin{array}{l}\text { Incorrect or } \\
\text { Don't know }\end{array}$} & \multicolumn{2}{|c|}{$\begin{array}{l}\text { Correct \& } \\
\text { Incomplete }\end{array}$} & \multicolumn{2}{|c|}{$\begin{array}{l}\text { Correct \& } \\
\text { Complete }\end{array}$} & & & \\
\hline & No & $\%$ & No & $\%$ & No & $\%$ & No & $\%$ & No & $\%$ & No & $\%$ & No & $\%$ & No & $\%$ & No & $\%$ & & & \\
\hline Normal Level of Iron in the Blood & 27 & 67.5 & $\mathbf{0}$ & $\mathbf{0}$ & 13 & 32.5 & 9 & 31 & $\mathbf{0}$ & $\mathbf{0}$ & 31 & 77.5 & 11 & 27.5 & $\mathbf{0}$ & $\mathbf{0}$ & 29 & 72.5 & $\begin{array}{l}* 16.364 \\
\left(0.000^{\# \#}\right)\end{array}$ & $\begin{array}{l}* * 0.267 \\
(0.606)\end{array}$ & $\begin{array}{c}* * * 12.832 \\
\left(0.000^{* * 1}\right)\end{array}$ \\
\hline $\begin{array}{l}\text { Function of Iron Chelation } \\
\text { Therapy }\end{array}$ & 12 & 3 & 0 & 0 & 28 & 70 & $\mathbf{0}$ & 0 & 0 & $\mathbf{0}$ & 40 & 100 & 1 & 2.5 & $\mathbf{0}$ & $\mathbf{0}$ & 39 & 97.5 & $\begin{array}{l}{ }^{*} 14.118 \\
\left(0.000^{* \#}\right)\end{array}$ & $\begin{array}{l}{ }^{* * 1.013} \\
(0.314)\end{array}$ & $\begin{array}{l}* * * 11.114 \\
\left(0.001^{*}\right)\end{array}$ \\
\hline $\begin{array}{l}\text { Different Forms of Iron Chelation } \\
\text { Therapy }\end{array}$ & $\mathbf{0}$ & 0 & 16 & 40 & 24 & 60 & $\mathbf{0}$ & 0 & 4 & 10 & 36 & 90 & 0 & $\mathbf{0}$ & 4 & 10 & 36 & 90 & $\begin{array}{l}* 9.600 \\
\left(0.002^{*}\right) \\
\end{array}$ & $\begin{array}{l}* * 0.001 \\
(1.000) \\
\end{array}$ & $\begin{array}{r}* * * 9.600 \\
(0.002) \\
\end{array}$ \\
\hline $\begin{array}{l}\text { Affection of Body Organs by Iron } \\
\text { Precipitation }\end{array}$ & 7 & 17.5 & $\mathbf{0}$ & $\mathbf{0}$ & 32 & 80 & $\mathbf{0}$ & 0 & 1 & 2.5 & 39 & 97.5 & $\mathbf{0}$ & $\mathbf{0}$ & 1 & 2.5 & 39 & 97.5 & $\begin{array}{c}* 8.679 \\
\left(0.013^{*}\right)\end{array}$ & $\begin{array}{l}* * 0.001 \\
(1.000)\end{array}$ & $\begin{array}{r}* * * 8.679 \\
\left(0.013^{*}\right)\end{array}$ \\
\hline $\begin{array}{l}\text { Organs Affected by Iron } \\
\text { Precipitation }\end{array}$ & 4 & 12.5 & 13 & 40. & 15 & 37.5 & 2 & 6.3 & 5 & 15.6 & 25 & 78.1 & 4 & 12.5 & 8 & 25 & 20 & 62.5 & $\begin{aligned} * 6.722 \\
\left(0.035^{*}\right)\end{aligned}$ & $\begin{array}{l}* * 1.915 \\
(0.384)\end{array}$ & $\begin{array}{r}* * * 1.908 \\
(0.368)\end{array}$ \\
\hline $\begin{array}{l}\text { The Most Common Types of Iron } \\
\text { Chelation Therapy }\end{array}$ & 0 & $\mathbf{0}$ & 8 & 20 & 32 & 80 & $\mathbf{0}$ & 0 & $\mathbf{0}$ & $\mathbf{0}$ & 40 & 100 & 0 & $\mathbf{0}$ & $\mathbf{0}$ & $\mathbf{0}$ & 40 & 100 & $\begin{array}{l}* 8.889 \\
\left(0.003^{*}\right)\end{array}$ & $\cdots$ & $\begin{array}{l}* * * 8.889 \\
\left(0.005^{*}\right)\end{array}$ \\
\hline $\begin{array}{l}\text { Frequency of Desferal the Child } \\
\text { Needs Weekly }\end{array}$ & 5 & 12.5 & $\mathbf{0}$ & $\mathbf{0}$ & 25 & 62.5 & 4 & 10 & $\mathbf{0}$ & $\mathbf{0}$ & 36 & 90 & $\mathbf{0}$ & $\mathbf{0}$ & 6 & 15 & 34 & 85 & $\begin{array}{l}* 0.680 \\
(0.410)\end{array}$ & $\begin{array}{l}* * 10.057 \\
\left(0.007^{*}\right)\end{array}$ & $\begin{array}{c}* * * 11.172 \\
\left(0.004^{*}\right)\end{array}$ \\
\hline $\begin{array}{l}\text { Methods of Desferal } \\
\text { Administration }\end{array}$ & $\mathbf{0}$ & $\mathbf{0}$ & 0 & 0 & 40 & 100 & $\mathbf{0}$ & 0 & $\mathbf{0}$ & $\mathbf{0}$ & 40 & 100 & $\mathbf{0}$ & 0 & $\mathbf{0}$ & $\mathbf{0}$ & 40 & 100 & 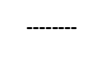 & -..-- & --.-- \\
\hline $\begin{array}{l}\text { Preferred Site for Desferal } \\
\text { Administration }\end{array}$ & 4 & 10 & $\mathbf{0}$ & 0 & 36 & 90 & $\mathbf{0}$ & 0 & $\mathbf{0}$ & $\mathbf{0}$ & 40 & 100 & 2 & 5 & 0 & $\mathbf{0}$ & 38 & 95 & $\begin{array}{l}* 4.211 \\
\left(0.04^{*}\right)\end{array}$ & $\begin{array}{l}* * 2.051 \\
(0.152)\end{array}$ & $\begin{array}{r}* * * 3.471 \\
(0.062)\end{array}$ \\
\hline
\end{tabular}

\#Significant at level $\mathrm{P}<0.05$

* Before the Nursing care protocol and immediately after the nursing care protocol

** Immediately after the nursing care protocol and 3 months after the Nursing care protocol

*** Before the nursing care protocol and 3 months after the nursing care protocol 
Table (5): The percentage of the Distribution of the Studied Nurses' Knowledge Regarding Desferal

\begin{tabular}{|c|c|c|c|c|c|c|c|c|c|c|c|c|c|c|c|c|c|c|c|c|c|}
\hline \multirow[t]{3}{*}{ Nurses' Knowledge } & \multicolumn{6}{|c|}{$\begin{array}{l}\text { Before the Nursing Care Protocol } \\
\qquad\left(\mathbf{n o}^{-40)}\right.\end{array}$} & \multicolumn{6}{|c|}{$\begin{array}{l}\text { Immediately After the Nursing Care Protocol } \\
\qquad(\text { no }=40)\end{array}$} & \multicolumn{6}{|c|}{$\begin{array}{l}3 \text { Months After the Nursing Care Protocol } \\
(\mathrm{no}=40)\end{array}$} & \multirow{3}{*}{$\begin{array}{c}\chi^{2} \\
\text { p-value }\end{array}$} & \multirow{3}{*}{$\begin{array}{c}\chi^{2} \\
\text { p-value }\end{array}$} & \multirow{3}{*}{$\begin{array}{c}\chi^{2} \\
\text { p-value }\end{array}$} \\
\hline & \multicolumn{2}{|c|}{$\begin{array}{c}\text { Incorrect } \\
\text { or Don't } \\
\text { know }\end{array}$} & \multicolumn{2}{|c|}{$\begin{array}{l}\text { Correct \& } \\
\text { Incomplete }\end{array}$} & \multicolumn{2}{|c|}{$\begin{array}{l}\text { Correct \& } \\
\text { Complete }\end{array}$} & \multicolumn{2}{|c|}{$\begin{array}{l}\text { Incorrect or } \\
\text { Don't know }\end{array}$} & \multicolumn{2}{|c|}{$\begin{array}{c}\text { Correct \& } \\
\text { Incomplete }\end{array}$} & \multicolumn{2}{|c|}{$\begin{array}{c}\text { Correct \& } \\
\text { Complete }\end{array}$} & \multicolumn{2}{|c|}{$\begin{array}{r}\text { Incorrect } \\
\text { or Don't } \\
\text { know }\end{array}$} & \multicolumn{2}{|c|}{$\begin{array}{l}\text { Correct \& } \\
\text { Incomplete }\end{array}$} & \multicolumn{2}{|c|}{$\begin{array}{l}\text { Correct \& } \\
\text { Complete }\end{array}$} & & & \\
\hline & No & $\%$ & No & $\%$ & No & $\%$ & No & $\%$ & No & $\%$ & No & $\%$ & $\mid \begin{array}{c}N \\
0\end{array}$ & $\%$ & No & $\%$ & No & $\%$ & & & \\
\hline $\begin{array}{l}\text { Indications for the Child's Need for } \\
\text { Desferal. }\end{array}$ & 0 & $\mathbf{0}$ & 10 & 25 & 30 & 75 & 0 & 0 & 3 & 7.5 & 37 & 92.5 & 0 & $\mathbf{0}$ & 5 & 12.5 & 35 & 87.5 & $\begin{array}{rl}* & * .501 \\
\left(0.034^{*}\right)\end{array}$ & $\begin{array}{l}* * 0.556 \\
(0.456)\end{array}$ & $\begin{array}{l}{ }^{* * * 2.051} \\
(0.152)\end{array}$ \\
\hline Side Effects of Desferal & 2 & 5 & 27 & 67.5 & 11 & 27.5 & 0 & $\mathbf{0}$ & 3 & 7.5 & 37 & 92.5 & 0 & 0 & 5 & 12.5 & 35 & 87.5 & $\begin{array}{l}* 35.283 \\
\left(0.000^{* \prime \prime}\right)\end{array}$ & $\begin{array}{l}* * 0.556 \\
(0.456)\end{array}$ & $\begin{array}{l}* * * 29.647 \\
\left(0.000^{* *}\right)\end{array}$ \\
\hline $\begin{array}{l}\text { Precautions Should be Considered to } \\
\text { Avoid Desferal's Side Effects }\end{array}$ & 20 & 50 & 4 & 10 & 16 & 40 & $\mathbf{0}$ & 0 & 4 & 10 & 36 & 90 & 0 & 0 & 6 & 15 & 34 & 85 & $\begin{array}{l}* 27.692 \\
\left(0.000^{* \prime \prime}\right)\end{array}$ & $\begin{array}{l}* * 0.457 \\
(0.499)\end{array}$ & $\begin{array}{c}* * * 26.880 \\
\left(0.000^{* * 1}\right)\end{array}$ \\
\hline $\begin{array}{l}\text { In Case of Complications; Stop } \\
\text { Desferal or Wait Physician } \\
\text { Counseling }\end{array}$ & $\mathbf{0}$ & $\mathbf{0}$ & 18 & 45 & 22 & 55 & $\mathbf{0}$ & $\mathbf{0}$ & 14 & 35 & 26 & 67 & 0 & 0 & 9 & 22.5 & 31 & 77.5 & $\begin{array}{l}* 0.833 \\
(0.361)\end{array}$ & $\begin{array}{l}* * 1.526 \\
(0.217)\end{array}$ & $\begin{array}{l}* * * 4.522 \\
\left(0.033^{*}\right)\end{array}$ \\
\hline
\end{tabular}

${ }^{\#}$ Significant at level $\mathrm{P}<0.05$

* Before the nursing-care protocol and immediately after the nursing-care protocol

*** Immediately after the nursing-care protocol and 3 months after the nursing-care protocol

** Before the nursing-care protocol and 3 months after the nursing-care protoc 


\section{Tanta Scientific Nursing Journal}

Table (6): the Percentage OF the Distribution of the Nurses' Knowledge Regarding Blood and Blood Transfusion

\begin{tabular}{|c|c|c|c|c|c|c|c|c|c|c|c|c|c|c|c|c|c|c|c|c|c|}
\hline \multirow[t]{3}{*}{ Nurses' Knowledge } & \multicolumn{6}{|c|}{$\begin{array}{l}\text { Before the Nursing care protocol } \\
\qquad(\mathrm{no}=40)\end{array}$} & \multicolumn{6}{|c|}{$\begin{array}{l}\text { Immediately After the Nursing Care Protocol } \\
\qquad(\mathbf{n}=\mathbf{4 0})\end{array}$} & \multicolumn{6}{|c|}{$\begin{array}{l}3 \text { Months After the Nursing Care Protocol } \\
\qquad(\mathrm{no}=40)\end{array}$} & \multirow{3}{*}{$\begin{array}{c}\chi^{2} \\
\text { p- } \\
\text { value }\end{array}$} & \multirow{3}{*}{$\begin{array}{c}\chi^{2} \\
\text { p-value }\end{array}$} & \multirow{3}{*}{$\begin{array}{c}\chi^{2} \\
\text { p- } \\
\text { value }\end{array}$} \\
\hline & \multicolumn{2}{|c|}{$\begin{array}{l}\text { Incorrect or } \\
\text { Don't know }\end{array}$} & \multicolumn{2}{|c|}{$\begin{array}{c}\text { Correct \& } \\
\text { Incomplete }\end{array}$} & \multicolumn{2}{|c|}{$\begin{array}{l}\text { Correct \& } \\
\text { Complete }\end{array}$} & \multicolumn{2}{|c|}{$\begin{array}{l}\text { Incorrect or } \\
\text { Don't know }\end{array}$} & \multicolumn{2}{|c|}{$\begin{array}{c}\text { Correct \& } \\
\text { Incomplete } \\
\end{array}$} & \multicolumn{2}{|c|}{$\begin{array}{c}\text { Correct \& } \\
\text { Complete }\end{array}$} & \multicolumn{2}{|c|}{$\begin{array}{l}\text { Incorrect or } \\
\text { Don't know }\end{array}$} & \multicolumn{2}{|c|}{$\begin{array}{c}\text { Correct \& } \\
\text { Incomplete } \\
\end{array}$} & \multicolumn{2}{|c|}{$\begin{array}{c}\text { Correct \& } \\
\text { Complete } \\
\end{array}$} & & & \\
\hline & No & $\%$ & No & $\%$ & No & $\%$ & No & $\%$ & No & $\%$ & $\begin{array}{lll}\text { No } \\
\end{array}$ & $\%$ & No & $\%$ & No & $\%$ & No & $\%$ & & & \\
\hline Components of Blood & 0 & $\mathbf{0}$ & 22 & 55 & 18 & 45 & $\mathbf{0}$ & $\mathbf{0}$ & 0 & $\mathbf{0}$ & 40 & 100 & $\mathbf{0}$ & $\mathbf{0}$ & 2 & 5 & 38 & 95 & $\mid \begin{array}{l}* 30.345 \\
\left(0.000^{\# \#}\right)\end{array}$ & $\begin{array}{l}* * 2.051 \\
(0.152)\end{array}$ & $\begin{aligned} * * * 23.18 \\
0 \\
\left(0.000^{\#+1}\right)\end{aligned}$ \\
\hline $\begin{array}{l}\text { Function of blood in the } \\
\text { body }\end{array}$ & 1 & 2.5 & 11 & 27.5 & 28 & 70 & 0 & 0 & 0 & $\mathbf{0}$ & 40 & 100 & $\mathbf{0}$ & 0 & 2 & 5 & 38 & 95 & $\begin{array}{c}14.11 \\
8 \\
(0.001 \\
\left(\begin{array}{l}* \\
)\end{array}\right. \\
\end{array}$ & $\begin{array}{l}* * 2.051 \\
(0.152)\end{array}$ & $\begin{array}{c}* * 8.4 \\
76 \\
(0.013 \\
*) \\
\end{array}$ \\
\hline $\begin{array}{l}\text { Child's Normal } \\
\text { Hemoglobin Level }\end{array}$ & 21 & 52.5 & 7 & 17.5 & 12 & 30 & 0 & $\mathbf{0}$ & 0 & $\mathbf{0}$ & 35 & 87.5 & 5 & 12.5 & 13 & 32.5 & 22 & 55 & \begin{tabular}{||c}
$* 39.09$ \\
6 \\
$\left(0.000^{\# \#}\right)$
\end{tabular} & $\begin{array}{l}* * 20.724 \\
\left(0.000^{* * 1}\right)\end{array}$ & $\begin{array}{c}* * * 14.58 \\
7 \\
\left(0.001^{*}\right)\end{array}$ \\
\hline $\begin{array}{l}\text { Effect of Regular Blood } \\
\text { Transusion on } \\
\text { Increasing Iron Level }\end{array}$ & 10 & 25 & $\mathbf{0}$ & $\mathbf{0}$ & 30 & 75 & 0 & $\mathbf{0}$ & 0 & $\mathbf{0}$ & 40 & 100 & 2 & 5 & $\mathbf{0}$ & $\mathbf{0}$ & 38 & 95 & $\begin{array}{c}{ }_{111.42} \\
9 \\
(0.001 \\
\left.{ }^{\prime}\right)\end{array}$ & $\begin{array}{l}* * 2.051 \\
(0.152)\end{array}$ & $\begin{array}{c}* * * 6.2 \\
75 \\
(0.012 \\
\left.{ }^{*}\right)\end{array}$ \\
\hline $\begin{array}{l}\text { Indications for the } \\
\text { Child's Need for Blood } \\
\text { Transfusion }\end{array}$ & 2 & 5 & 21 & 52.5 & 12 & 40 & $\mathbf{0}$ & $\mathbf{0}$ & 8 & 20 & 32 & 80 & $\mathbf{0}$ & $\mathbf{0}$ & 9 & 20 & 80 & 31 & $\mid \begin{array}{l}* 16.659 \\
\left(0.000^{\# \prime \prime}\right)\end{array}$ & $\begin{array}{l}* * 0.075 \\
(0.785)\end{array}$ & $\begin{array}{l}* * * 14.92 \\
8 \\
\left(0.011^{*}\right)\end{array}$ \\
\hline $\begin{array}{l}\text { Benefits of Blood } \\
\text { Transfusion }\end{array}$ & 4 & 10 & 20 & 50 & 16 & 40 & 3 & 7.5 & 5 & 12.5 & 32 & 80 & $\mathbf{0}$ & $\mathbf{0}$ & 36 & 90 & 4 & 10 & $\begin{array}{l}14.47 \\
6 \\
(0.001 \\
\left.{ }^{*}\right)\end{array}$ & $\begin{array}{l}* * 48.217 \\
\left(0.000^{\# \prime}\right)\end{array}$ & $\begin{array}{r}* * * 15 . \\
771 \\
\left(0.000^{* \prime \prime}\right)\end{array}$ \\
\hline $\begin{array}{l}\text { Complications of Blood } \\
\text { Transfusion may be } \\
\text { Present }\end{array}$ & 11 & 27.5 & $\mathbf{0}$ & $\mathbf{0}$ & 29 & 72.5 & 2 & 5 & 0 & $\mathbf{0}$ & 38 & 95 & $\mathbf{0}$ & 0 & $\mathbf{0}$ & $\mathbf{0}$ & 40 & 100 & $\begin{array}{l}* 7.440 \\
(0.006 \\
\left.{ }_{1}\right)\end{array}$ & $\begin{array}{l}* * 2.051 \\
(0.152)\end{array}$ & $\begin{array}{c}* * * 12 . \\
754 \\
(0.000 \\
(\#)\end{array}$ \\
\hline $\begin{array}{l}\text { Body Response to } \\
\text { Complications of Blood } \\
\text { Transfusion }\end{array}$ & 0 & $\mathbf{0}$ & 23 & 79.3 & 6 & 20.9 & $\mathbf{0}$ & $\mathbf{0}$ & 4 & 13.8 & 25 & 86.2 & $\mathbf{0}$ & 0 & 9 & 31.0 & 20 & 68.9 & $\begin{array}{c}*_{25.01} \\
6 \\
(0.000 \\
\text { 耘) }\end{array}$ & $\begin{array}{l}* * 2.479 \\
(0.115)\end{array}$ & $\begin{array}{c}* * * 13 . \\
663 \\
(0.000 \\
\left.{ }^{* \prime \prime}\right)\end{array}$ \\
\hline
\end{tabular}

Significant at level $\mathrm{P}<0.05$

* Before the nursing-care protocol and immediately after the nursing-care protocol

** Immediately after the nursing-care protocol and 3 months after the nursing-care protocol

*** Before the Nursing-care protocol and 3 months after the nursing-care protocol 
Table (7): The percentage of the Distribution of Studied Nurses' Knowledge Regarding Nutritional Assessment of Thalassemic Children

\begin{tabular}{|c|c|c|c|c|c|c|c|c|c|c|c|c|c|c|c|c|c|c|c|c|c|}
\hline \multirow{3}{*}{ Nurses' Knowledge } & \multicolumn{6}{|c|}{$\begin{array}{l}\text { Before the Nursing-Care Protocol } \\
\qquad(\mathrm{no}=\mathbf{4 0 )}\end{array}$} & \multicolumn{6}{|c|}{$\begin{array}{l}\text { Immediately After the Nursing-Care } \\
\text { Protocol } \\
(\text { no=40) }\end{array}$} & \multicolumn{6}{|c|}{$\begin{array}{l}3 \text { Months After the Nursing-Care Protocol } \\
\qquad(\text { no=40) }\end{array}$} & \multirow{3}{*}{$\begin{array}{c}\chi^{2} \\
\text { p-value }\end{array}$} & \multirow{3}{*}{$\begin{array}{c}\chi^{2} \\
\text { p-value }\end{array}$} & \multirow{3}{*}{$\begin{array}{c}\chi^{2} \\
\text { p-value }\end{array}$} \\
\hline & \multicolumn{2}{|c|}{$\begin{array}{l}\text { Incorrect } \\
\text { or Don't } \\
\text { know }\end{array}$} & \multicolumn{2}{|c|}{$\begin{array}{c}\text { Correct \& } \\
\text { Incomplet } \\
\quad \text { e }\end{array}$} & \multicolumn{2}{|c|}{$\begin{array}{l}\text { Correct \& } \\
\text { Complete }\end{array}$} & \multicolumn{2}{|c|}{$\begin{array}{l}\text { Incorrect } \\
\text { or Don't } \\
\text { know }\end{array}$} & \multicolumn{2}{|c|}{$\begin{array}{c}\text { Correct \& } \\
\text { Incomplete }\end{array}$} & \multicolumn{2}{|c|}{$\begin{array}{l}\text { Correct \& } \\
\text { Complete }\end{array}$} & \multicolumn{2}{|c|}{$\begin{array}{l}\text { Incorrect } \\
\text { or Don't } \\
\text { know }\end{array}$} & \multicolumn{2}{|c|}{$\begin{array}{l}\text { Correct \& } \\
\text { Incomplete }\end{array}$} & \multicolumn{2}{|c|}{$\begin{array}{l}\text { Correct \& } \\
\text { Complete }\end{array}$} & & & \\
\hline & $\begin{array}{l}\mathbf{N} \\
\mathbf{o}\end{array}$ & $\%$ & No & $\%$ & $\mathbf{N}$ & $\%$ & $\begin{array}{l}\mathbf{N} \\
\mathbf{o}\end{array}$ & $\%$ & No & $\%$ & No & $\%$ & $\begin{array}{l}\mathbf{N} \\
\mathbf{o}\end{array}$ & $\%$ & $\mathbf{N}$ & $\%$ & $\mathbf{N}$ & $\%$ & & & \\
\hline Types of Foods Which Rich in Iron & $\mathbf{0}$ & $\mathbf{0}$ & 15 & $\begin{array}{c}37 . \\
5\end{array}$ & $2:$ & 62.5 & $\mathbf{0}$ & 0 & 4 & 10 & 36 & 92.5 & $\mathbf{0}$ & $\mathbf{0}$ & 2 & 5 & 38 & 95 & $\begin{array}{c}* 8.352 \\
\left(0.004^{\#}\right)\end{array}$ & $\begin{array}{c}* * 0.721 \\
(\mathbf{0 . 3 9 6})\end{array}$ & $\begin{array}{c}* * * 12.624 \\
\left(0.001^{\#}\right)\end{array}$ \\
\hline $\begin{array}{l}\text { Foods or Drinks which Decrease the } \\
\text { Absorption of Iron }\end{array}$ & 1 & 2.5 & 38 & 95 & 1 & 2.5 & $\mathbf{0}$ & $\mathbf{0}$ & 3 & 7.5 & 37 & 92.5 & $\mathbf{0}$ & $\mathbf{0}$ & 6 & 15 & 3 & 85 & $\begin{array}{c}\text { *64.983 } \\
\left(0.000^{\#}\right. \\
\quad)\end{array}$ & $\begin{array}{l}* * 1.127 \\
(\mathbf{0 . 2 8 8})\end{array}$ & $\begin{array}{r}* * * 55.387 \\
\left(\mathbf{0 . 0 0 0} 0^{* \#}\right)\end{array}$ \\
\hline $\begin{array}{l}\text { Foods or Drinks which Increase the } \\
\text { Absorption of Iron }\end{array}$ & 34 & 85 & 6 & 15 & $\mathbf{0}$ & $\mathbf{0}$ & 3 & 7.5 & 15 & 37.5 & 22 & 55 & 7 & 17.5 & 1 & 47.5 & 1 & 35 & $\begin{array}{c}\text { *19.168 } \\
\left(0.000^{\# \#}\right. \\
)\end{array}$ & $\begin{array}{r}* * 12.374 \\
\left(0.002^{*}\right)\end{array}$ & $\begin{array}{c}* * * 9.518 \\
\left(0.009^{*}\right)\end{array}$ \\
\hline
\end{tabular}

${ }^{\#}$ Statistically significant at level $\mathrm{P}<0.05$

* Before the nursing-care protocol and immediately after the nursing-care Protocol

** Immediately after the nursing-care protocol and 3 months after the nursing-care protocol 
Table (8): The percentage of the Distribution of Studied Nurses' Knowledge Regarding Laboratory Investigations of

\section{Thalassemic Children}

\begin{tabular}{|c|c|c|c|c|c|c|c|c|c|c|c|c|c|c|c|c|c|c|c|c|c|}
\hline \multirow{3}{*}{ Nurses' Knowledge } & \multicolumn{6}{|c|}{$\begin{array}{l}\text { Before the Nursing Care Protocol } \\
(\text { no=40) }\end{array}$} & \multicolumn{6}{|c|}{$\begin{array}{c}\text { Immediately After the Nursing Care } \\
\text { Protocol }(\text { no }=40)\end{array}$} & \multicolumn{6}{|c|}{$\begin{array}{c}3 \text { months After the Nursing Care Protocol (no } \\
\qquad=40 \text { ) }\end{array}$} & \multirow{3}{*}{$\begin{array}{c}\chi^{2} \\
\text { p-value }\end{array}$} & \multirow{3}{*}{$\begin{array}{c}\chi^{2} \\
\text { p-value }\end{array}$} & \multirow{3}{*}{$\begin{array}{c}\chi^{2} \\
\text { p-value }\end{array}$} \\
\hline & \multicolumn{2}{|c|}{$\begin{array}{l}\text { Incorrect } \\
\text { or Don't } \\
\text { know }\end{array}$} & \multicolumn{2}{|c|}{$\begin{array}{c}\text { Correct \& } \\
\text { Incomplet } \\
\text { e }\end{array}$} & \multicolumn{2}{|c|}{$\begin{array}{c}\text { Correct \& } \\
\text { Complete }\end{array}$} & \multicolumn{2}{|c|}{$\begin{array}{c}\text { Incorrect } \\
\text { or Don't } \\
\text { know }\end{array}$} & \multicolumn{2}{|c|}{$\begin{array}{c}\text { Correct \& } \\
\text { Incomplet } \\
\text { e }\end{array}$} & \multicolumn{2}{|c|}{$\begin{array}{l}\text { Correct \& } \\
\text { Complete }\end{array}$} & \multicolumn{2}{|c|}{$\begin{array}{l}\text { Incorrect } \\
\text { or Don't } \\
\text { know }\end{array}$} & \multicolumn{2}{|c|}{$\begin{array}{c}\text { Correct \& } \\
\text { Incomplete }\end{array}$} & \multicolumn{2}{|c|}{$\begin{array}{l}\text { Correct \& } \\
\text { Complete }\end{array}$} & & & \\
\hline & $\begin{array}{l}\mathbf{N} \\
\mathbf{o}\end{array}$ & $\%$ & No & $\%$ & No & $\%$ & No & $\%$ & No & $\%$ & No & $\%$ & No & $\%$ & No & $\%$ & No & $\%$ & & & \\
\hline $\begin{array}{l}\text { New Trends for } \\
\text { Investigations }\end{array}$ & $\mathbf{0}$ & $\mathbf{0}$ & 6 & 15 & 34 & 85 & $\mathbf{0}$ & $\mathbf{0}$ & 2 & 5 & 38 & 95 & $\mathbf{0}$ & $\mathbf{0}$ & 5 & 12.5 & 35 & 87.5 & $\begin{array}{l}* 2.222 \\
(0.136)\end{array}$ & $\begin{array}{l}* * 1.409 \\
(0.235)\end{array}$ & $\begin{array}{c}* * * 0.105 \\
(\mathbf{0 . 7 4 5})\end{array}$ \\
\hline $\begin{array}{l}\text { Importance of Premarital } \\
\text { Counseling }\end{array}$ & 4 & 10 & $\mathbf{0}$ & 0 & 36 & 90 & 0 & $\mathbf{0}$ & $\mathbf{0}$ & $\mathbf{0}$ & 40 & $\begin{array}{c}10 \\
0\end{array}$ & $\mathbf{0}$ & 0 & $\mathbf{0}$ & $\mathbf{0}$ & 40 & 100 & $\begin{array}{l}* 4.211 \\
\left(0.04^{\#}\right)\end{array}$ & --.- & $\begin{array}{c}* * 4.211 \\
\left(0.04^{*}\right)\end{array}$ \\
\hline $\begin{array}{l}\text { Follow up of Blood Analysis } \\
\text { for Hemoglobin Level }\end{array}$ & $\mathbf{0}$ & $\mathbf{0}$ & $\mathbf{0}$ & 0 & 40 & 100 & 0 & $\mathbf{0}$ & 0 & $\mathbf{0}$ & 40 & $\begin{array}{c}10 \\
0\end{array}$ & $\mathbf{0}$ & $\mathbf{0}$ & $\mathbf{0}$ & $\mathbf{0}$ & 40 & 100 & ------ & -.-- & -.---.- \\
\hline $\begin{array}{l}\text { Follow up of Blood Analysis } \\
\text { for Iron Level }\end{array}$ & 18 & 45 & 0 & 0 & 22 & 55 & 0 & 0 & 0 & $\mathbf{0}$ & 40 & $\begin{array}{c}10 \\
0\end{array}$ & 2 & 5 & 0 & $\mathbf{0}$ & 38 & 95 & $\begin{array}{l}* 23.226 \\
\left(0.000^{\# \#}\right)\end{array}$ & $\begin{array}{l}* * 2.051 \\
(0.152)\end{array}$ & $\begin{array}{c}* * * 17.067 \\
\left(0.000^{\# \#}\right)\end{array}$ \\
\hline
\end{tabular}

${ }^{\#}$ Statistically significant at level $\mathrm{P}<0.05$

* Before the nursing-care protocol and immediately after the nursing-care Protocol

** Immediately after the nursing-care protocol and 3 months after the nursing-care protocol

*** Before the nursing-care protocol and 3 months after nursing-care protocol 
Table (9): Percentage of the Distribution of the Studied Children Regarding their Percent of the Standard of the Anthropometric Measurement for Age and Sex.

\begin{tabular}{|c|c|c|c|c|c|c|c|c|c|}
\hline \multirow[t]{2}{*}{$\begin{array}{l}\text { Anthropometric } \\
\text { Measurement }\end{array}$} & \multicolumn{2}{|c|}{$\begin{array}{l}\text { Before the } \\
\text { Nursing Care } \\
\text { Protocol } \\
(\text { no=40) }\end{array}$} & \multicolumn{2}{|c|}{$\begin{array}{l}\text { Immediate } \\
\text { After the } \\
\text { Nursing Care } \\
\text { Protocol } \\
(\text { no=40) }\end{array}$} & \multicolumn{2}{|c|}{$\begin{array}{c}3 \text { Month } \\
\text { After the } \\
\text { Nursing Care } \\
\text { Protocol } \\
\text { (no=40) } \\
\end{array}$} & \multirow[t]{2}{*}{$\underset{\text { P-value }}{\chi^{2}}$} & \multirow[t]{2}{*}{$\begin{array}{c}\chi^{2} \\
\text { P-value }\end{array}$} & \multirow[t]{2}{*}{$\underset{\text { P-value }}{\chi^{2}}$} \\
\hline & No & $\%$ & No & $\%$ & No & $\%$ & & & \\
\hline \multicolumn{7}{|c|}{ Weight } & \multirow{4}{*}{$\begin{array}{l}* 2.460 \\
(0.116)\end{array}$} & \multirow{4}{*}{$\begin{array}{l}* * 0.830 \\
(0.361)\end{array}$} & \multirow{4}{*}{$\begin{array}{l}* * * 6.050 \\
\left(0.014^{\#}\right)\end{array}$} \\
\hline$<90 \%$ & 25 & 62.5 & 18 & 45 & 14 & 35 & & & \\
\hline $90 \%-110 \%$ & 13 & 32.5 & 20 & 50 & 24 & 60 & & & \\
\hline$>110 \%$ & 2 & 5 & 2 & 5 & 2 & 5 & & & \\
\hline \multicolumn{7}{|c|}{$\mathrm{M} \pm \mathrm{SD}$} & \multicolumn{3}{|c|}{$19.3 \pm 10.8$} \\
\hline \multicolumn{7}{|c|}{ Height } & \multirow{4}{*}{$\begin{array}{l}* 0.001 \\
(1.000)\end{array}$} & \multirow{4}{*}{$\begin{array}{l}* * 0.464 \\
(0.495)\end{array}$} & \multirow{4}{*}{$\begin{array}{r}* * * 0.464 \\
(0.496)\end{array}$} \\
\hline$<90 \%$ & 25 & 62.5 & 25 & 62.5 & 22 & 55 & & & \\
\hline $90 \%-110 \%$ & 15 & 37.5 & 15 & 37.5 & 18 & 45 & & & \\
\hline$>110 \%$ & $\mathbf{0}$ & 0.00 & $\mathbf{0}$ & 0.00 & $\mathbf{0}$ & 0.00 & & & \\
\hline \multicolumn{7}{|c|}{$\mathbf{M} \pm$ SD } & \multicolumn{3}{|c|}{$20.9 \pm 12.3$} \\
\hline \multicolumn{7}{|c|}{ Upper mid arm circumference } & \multirow{4}{*}{$\begin{array}{l}* 0.001 \\
(1.000)\end{array}$} & \multirow{4}{*}{$\begin{array}{l}* * 0.460 \\
(0.496)\end{array}$} & \multirow{4}{*}{$\begin{array}{l}* * * 1.270 \\
(\mathbf{0 . 2 6 0 )}\end{array}$} \\
\hline$<90 \%$ & 25 & 62.5 & 23 & $\mathbf{5 7 . 5}$ & 20 & 50 & & & \\
\hline $90 \%-110 \%$ & 13 & 32.5 & 15 & 37.5 & 19 & 47.5 & & & \\
\hline$>110 \%$ & 2 & 5 & 2 & 5 & 1 & 2.5 & & & \\
\hline \multicolumn{7}{|c|}{$\mathbf{M} \pm \mathrm{SD}$} & \multicolumn{3}{|c|}{$19.3 \pm 10.9$} \\
\hline \multicolumn{7}{|c|}{ Skin-fold thickness } & \multirow{4}{*}{$\begin{array}{l}* 0.030 \\
(\mathbf{0 . 8 6 5 )}\end{array}$} & \multirow{4}{*}{$\begin{array}{l}* * 1.800 \\
(0.179)\end{array}$} & \multirow{4}{*}{$\begin{array}{c}* * * 3.230 \\
(\mathbf{0 . 0 7 2})\end{array}$} \\
\hline$<\mathbf{8 0 \%}$ & 26 & 65 & 24 & 60 & 18 & 45 & & & \\
\hline $80 \%-110 \%$ & 12 & 30 & 14 & 35 & 21 & 52.5 & & & \\
\hline$>110 \%$ & 2 & 5 & 2 & 5 & 1 & 2.5 & & & \\
\hline \multicolumn{7}{|c|}{$\mathrm{M} \pm \mathrm{SD}$} & \multicolumn{3}{|c|}{$19.7 \pm 11.3$} \\
\hline
\end{tabular}

\# Significant at level P $<0.05$

* Before the nursing care protocol and immediately after the nursing care protocol ** Immediately after the nursing care protocol and 3 months after the nursing care protocol **** Before the nursing care protocol and 3 months after the nursing care protocol 


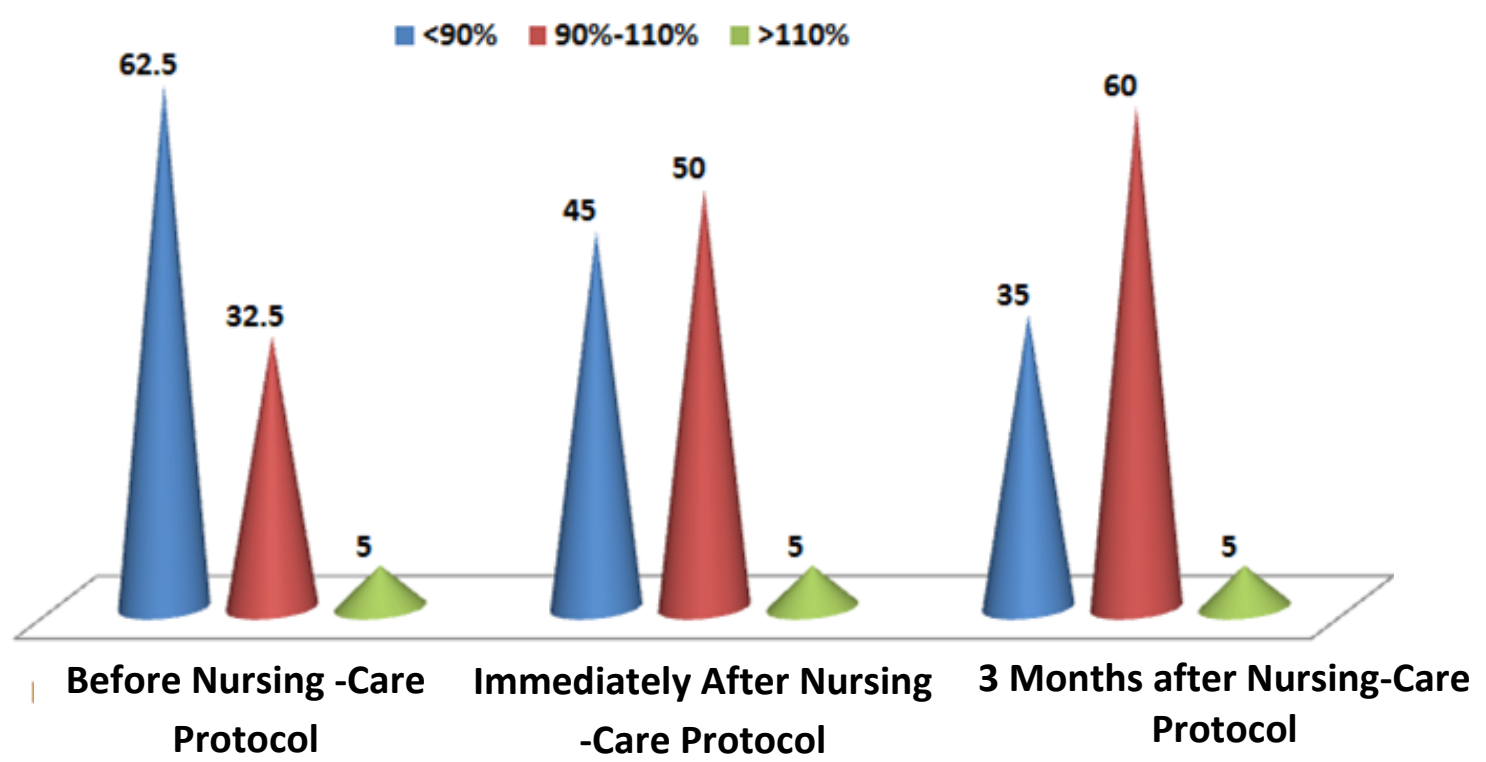

Figure (3): The percentage distribution of the studied children regarding their percent of the standard weight measurement for age and sex.

$-<90 \% \quad-90 \%-110 \% \quad->110 \%$

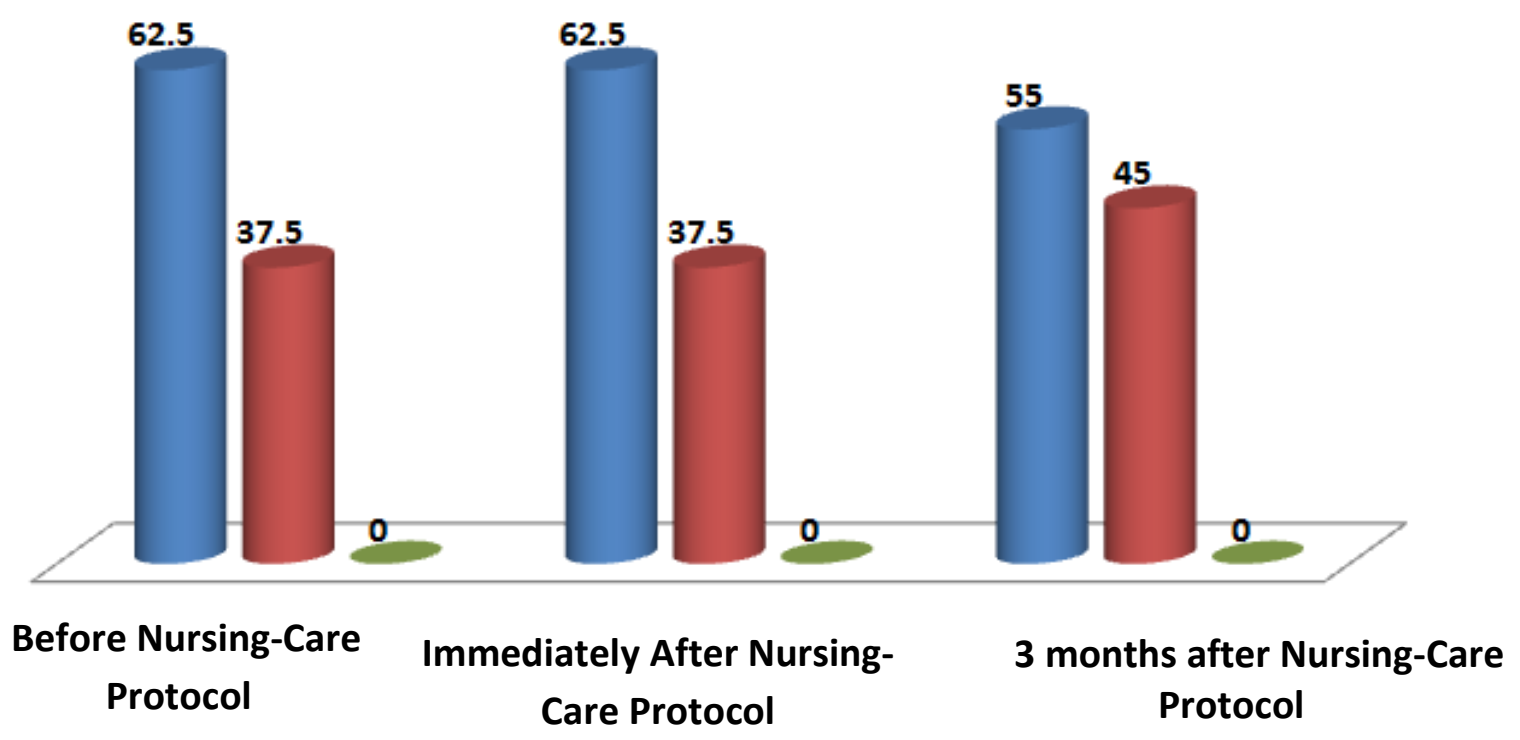

Figure (4): The percentage of the distribution of the studied children regarding their percent of the standard height measurement for age and sex. 
$-<90 \%=90 \%-110 \%=>110 \%$

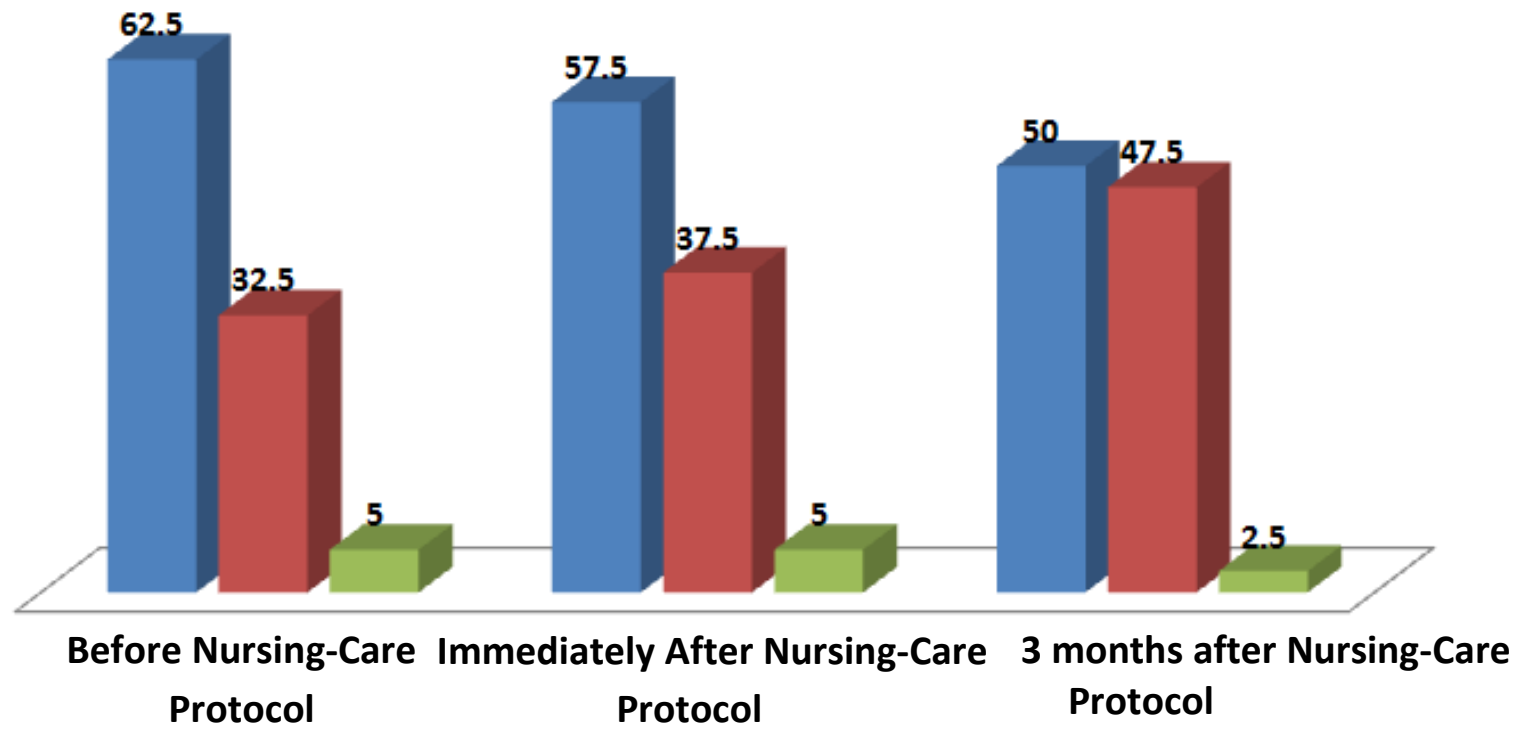

Figure (5): The percentage of the distribution of the studied children regarding their percent of the standard upper mid arms circumference for age and sex.

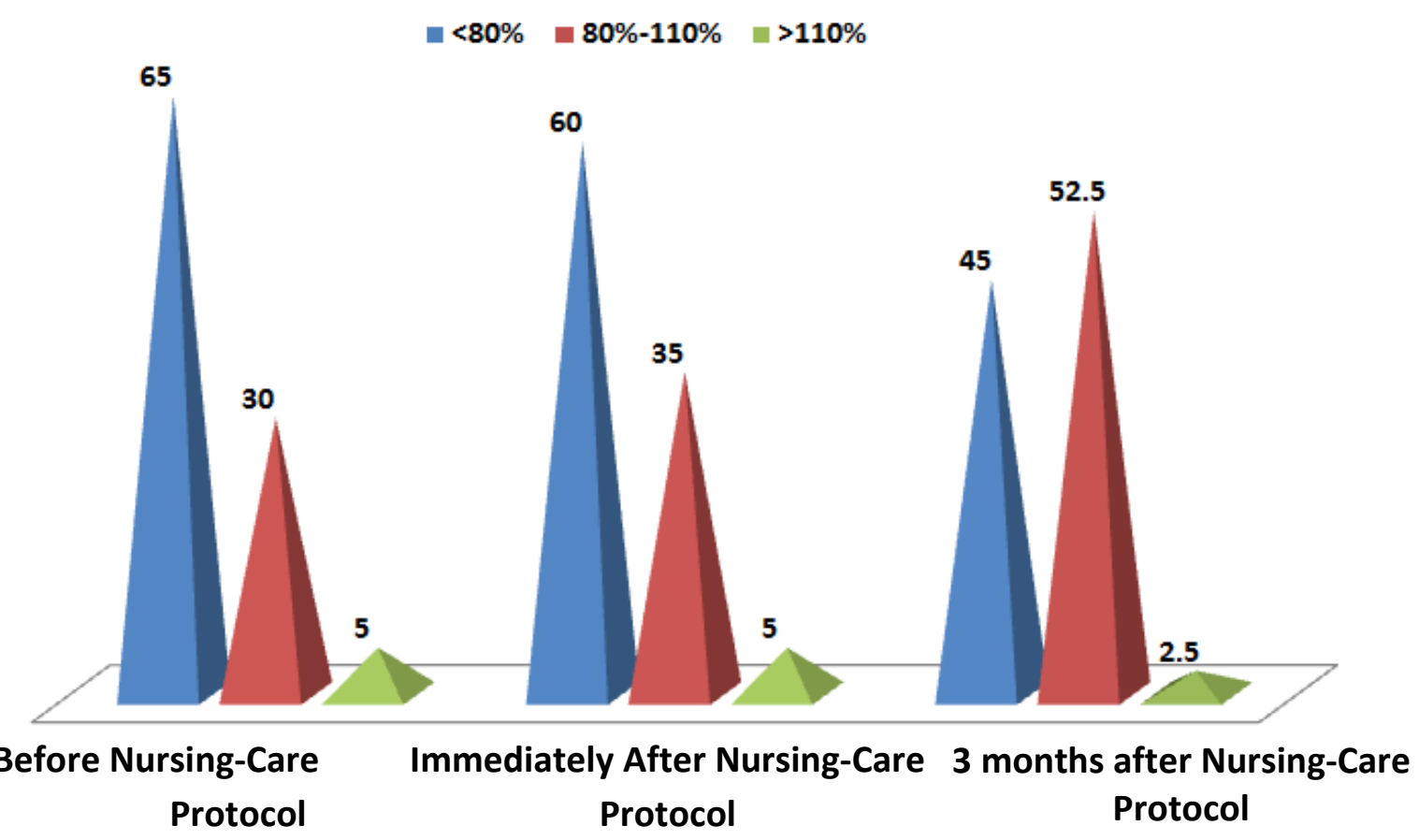

Figure (6): The percent of the distribution of the studied children regarding their percent of the standard skin fold thickness measurement for age and sex. 
Table (10): Precentage Distribution of the Studied Children Regarding their Percent of the Standard of Body Mass Index

\begin{tabular}{|c|c|c|c|c|c|c|c|c|c|}
\hline \multirow[t]{2}{*}{$\begin{array}{l}\text { Standard Body Mass } \\
\text { Index }(\mathrm{kg} / \mathrm{m} 2)\end{array}$} & \multicolumn{2}{|c|}{$\begin{array}{c}\text { Before the } \\
\text { Nursing-Care } \\
\text { Protocol } \\
(\text { no=40) } \\
\end{array}$} & \multicolumn{2}{|c|}{$\begin{array}{c}\text { Immediately After } \\
\text { the Nursing-Care } \\
\text { Protocol } \\
(\text { no=40) }\end{array}$} & \multicolumn{2}{|c|}{$\begin{array}{l}\text { Months After the } \\
\text { Nursing- Care } \\
\text { Protocol } \\
(\text { no=40) }\end{array}$} & \multirow[t]{2}{*}{$\begin{array}{c}\chi^{2} \\
\text { P-value }\end{array}$} & \multirow[t]{2}{*}{$\begin{array}{c}\chi^{2} \\
\text { P-value }\end{array}$} & \multirow[t]{2}{*}{$\begin{array}{c}\chi^{2} \\
\text { P-value }\end{array}$} \\
\hline & No & $\%$ & No & $\%$ & No & $\%$ & & & \\
\hline "Underweight $<18.5$ & 26 & 65 & 19 & 47.5 & 15 & 37.5 & \multirow{3}{*}{$\begin{array}{l}* 2.670 \\
(0.263)\end{array}$} & \multirow{3}{*}{$\begin{array}{l}* * 6.408 \\
\left(0.041^{\#}\right)\end{array}$} & \multirow{3}{*}{$\begin{array}{c}* \\
* * 0.852 \\
(\mathbf{0 . 6 5 3 )}\end{array}$} \\
\hline Normal 18.5-24.9 & 12 & 30 & 19 & 47.5 & 23 & $\mathbf{5 7 . 5}$ & & & \\
\hline Overweight 25-29.9 & 2 & 5 & 2 & 5 & 2 & 5 & & & \\
\hline \multicolumn{7}{|c|}{$\mathbf{M} \pm$ SD } & \multicolumn{3}{|c|}{$19.2 \pm 10.8$} \\
\hline
\end{tabular}

${ }^{\#}$ Significant at level $\mathrm{P}<0.05$

* Before the nursing-care protocol and immediately after the nursing-care Protocol

** Immediately after the nursing-care protocol and 3 months after the nursing-care protocol

*** Before the nursing-care protocol and 3 months after nursing-care protocol

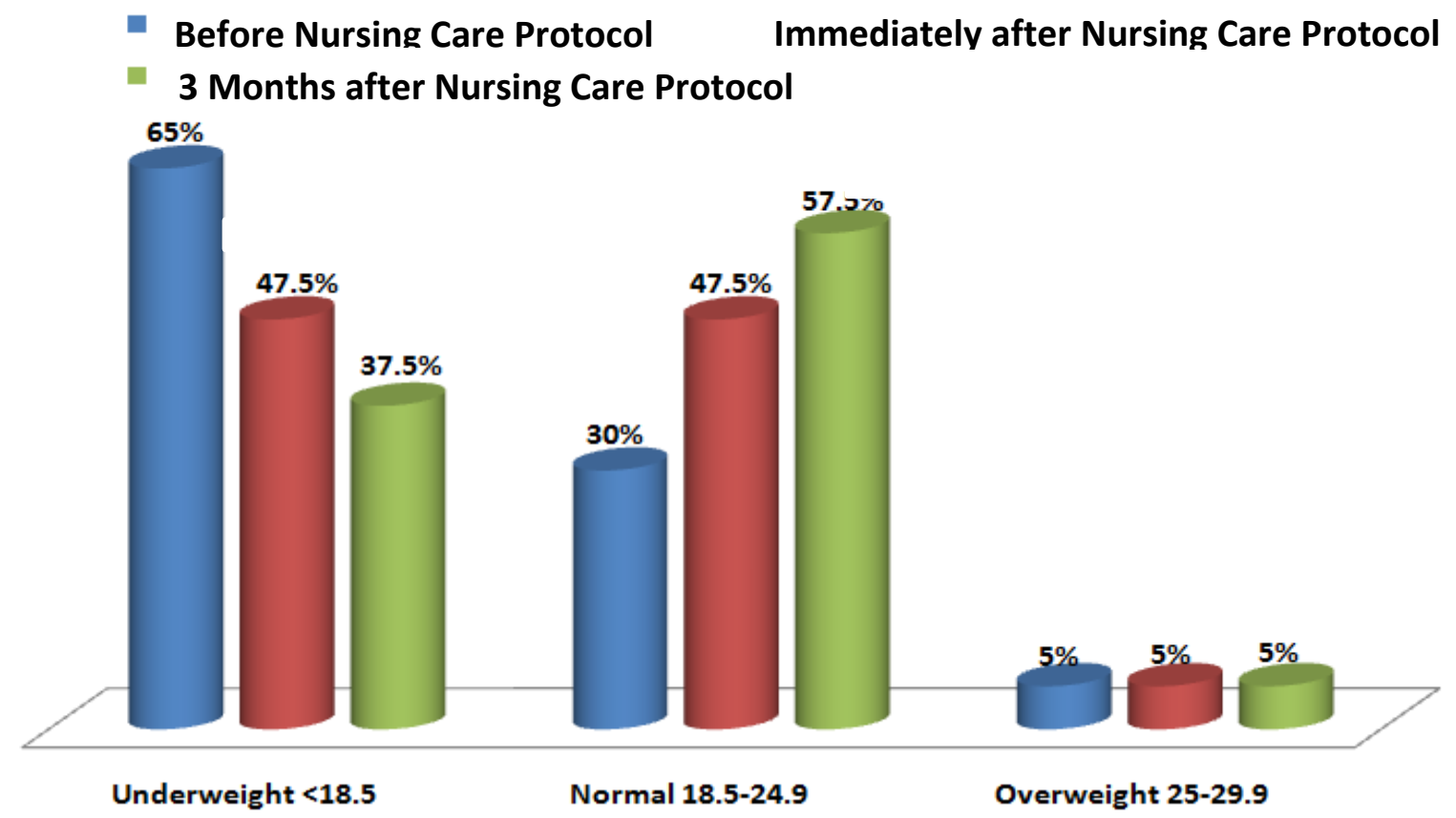

Figure (11): The percent of the distribution of the studied children regarding their percent of the standard body mass index for age and sex 


\section{Discussion}

Thalassemia is an autosomal genetic disease characterized by anemia and attributed to the underproduction of globin proteins. This disease is more prevalent in people living in the Mediterranean region. The hemoglobin molecule is composed of two alpha chains and two beta ones. Thalassemia can categorize on the basis at the globin chains affected by Alpha, Beta and Delta thalassemia. ${ }^{(1,3)}$

The outcome of thalassemic children is an objective measure of goal achievement. Meeting outcomes resolves the etiology at nursing diagnosis . The nurse evaluates the child's progress toward achievement. The plan of care depends on the implementation, interpretation whether continuous or revised. The nurse plays an important role for the care of thalassemic children which helps to improve the quality of life and facilitate the child's and family's adaptation to this illness. Monitoring chelation therapy achieves optimal outcome in the treatment of thalassemia. All thalassemic children should undergo at least an annual comprehensive assessment. During such an assessment, recommendations are summarized and communicated directly to the primary provider and family. Primary care includes monitoring of growth and general health. ${ }^{(2,100)}$

The present study has revealed that nursing students graduated from secondary school after 3 years only at the age of about 18 years. In this study, most of studied nurses were secondary school graduates and had 10 years of experience or more. This result is in disagreement with Laeau (2009) ${ }^{(17)}$ who reported that more than half of the study participants had worked for 10 years or less. This result is in agreement with Ahmed (2012) ${ }^{(18)}$ who found that the majority of nursing team has diplomas. Less than half of nursing team has experience more than 10 years and all of them have no experience in courses of service training. Moreover, Hussain (2009) ${ }^{(19)}$ who reported that the majority of the nurses have general diplomas in nursing with average 12 years of experience. Also, Parajulee (2011) ${ }^{(20)}$ who found that the mean years of experience were 11.45 among the study group.

Regarding sex, the present study has revealed that thalassemia is present in boys more than girls are. These results are in agreement with Soliman (2010) ${ }^{(21)}$ who found that the percent of males was more than half of the studied children and Bassit 
(2014) ${ }^{(22)}$ who found that more than half of the studied children were males.

In this study, consanguinity was reported that in more than half of the studied children. Consanguinity is a social phenomenon among the Egyptian, especially in the rural areas. The traditions in Arabic countries cause increase in the relative marriage especially with the first cousin. This leads to an increase in homozygous of some conditions such as thalassemia. This result is in agreement with Hussien (2009) ${ }^{(19)}$ who reported that more than half of the studied children with beta thalassemia had consanguineous parents and Temtamy (2009) ${ }^{(23)}$ who reported that more than half of the studied children had consanguineous parents. This result is in disagreement with Soliman (2010) (21) who reported consanguinity only positive in 10 patients $(25 \%)$. This result was similar to the data published by Galanello and Origa (2010) ${ }^{(24)}$ who noted that $\beta$-thalassemia is inherited in an autosomal recessive manner. Bassit (2014) (22) is in agreement with my result, who reported that there was positive consanguinity in 55\%. These results explain the importance of premarital examination and counseling for the prevention and early detection of thalassemic children, especially in positive family history.

The present study has revealed that, nurses' knowledge of thalassemic children was low. This might be due to the fact that nurses didn't receive specific direct education. This result is in agreement with the result of EL-Ghlban (2013) ${ }^{(25)}$ who concluded that the causes of nurses, poor level of knowledge and practices were due to that there were not continuous education and training for nursing staff .

The present study has revealed that, signs and symptoms of the disease were the methods of diagnosis in minority of thalassemic children. Severe thalassemia can cause early death due to heart failure, usually between the ages of 20 to 30 . The minority of studied nurses knew these manifestations before the nursing care protocol. This result is in disagreement with Bassit (2014) ${ }^{(22)}$ who found that pallor is present in most of the thalassemic children while jaundice is present in less than half of the studied children. This result is contradictory to Soliman (2010) (21) who reported that pallor is present in most of the studied thalassemic children.

Regarding the information about desferal, studied children are currently managed by iron chelator (desferal) which greatly 
improves prognosis and extends the life span. It was noticed that the studied nurses had lack of the essential knowledge in this topic. The ability of the chelators to remove excess iron depends on (at least) two factors; the rate at which the chelator depletes storage iron and the rate of continued iron accumulation. This was confirmed by Abo-Salem (1999) ${ }^{(26)}$ who stated that it is difficult for the intellectual capacity of illiterate mothers to retain knowledge in their memory for a long time without reinforcement. This result also in the same line with Mater (2006) ${ }^{(27)}$ who found that lack of studied sample information about desferal.

The present study revealed that most of studied nurses used desferal as a therapy to get rid of iron overload before, immediately after and 3 months after the nursing-care protocol. The rest of studied children who showed non-compliance might be due to their lack of appreciation of the therapy, lack of desferal pump, money expended for transplantation of renting the desferal pump and sometimes the cost of desferal itself when it is not available in the clinic and / or the side effects. Compliance with chelation therapy is critical in prevention of iron-overload complications. These results are in agreement with Porter (2007) ${ }^{(28)}$ who published that desferal an effective and convenient iron-chelation therapy of iron overload. This study is in agreement also with Miskin (2003) ${ }^{(29)}$ who studied eight thalassemic children treated with intermittent (8-10 hours) intravenous desferoxamine with 7 year follow (84months). However, Desferoxamine is recommended by Taha (2013) ${ }^{(30)}$ who mentioned that desferoxamine the firstline therapy of iron chelation therapy in children with thalassemia major but deferipone or deferasirox was indicated for treating iron overload when desferoxamine was contraindicated or inadequate.

The present study revealed that the preferred method of desferal administration to attain maximum benefits over the decrease of side effects is subcutaneous administration for 8-12 hours a day daily for 5-7 days a week. This result is in agreement with Gomber (2004) (31), who observed that subcutaneous desferoxamine was the most effective chelating drug in iron-overloaded thalassemic children. The ferritin level maximally decreased after 6 months with subcutaneous therapy.

Regarding the information about anemia, thalassemia, chelation therapy and blood transfusion, it was noticed sharp increase of nurses' knowledge immediately after 
nursing the care protocol with a little drop for 3 months after the nursing careprotocol. This result is in agreement with Madden (2000) ${ }^{(32)}$ and Broom (1996) ${ }^{(33)}$ who supported the result by following training for the protocol of cares in which there is a significant acquisition of nurses' cognitive knowledge. In addition, Inwood (1996) ${ }^{(34)}$ and Moule (1997) ${ }^{(35)}$ who were in agreement with the current study found a significant improvement of nurses' knowledge after training for the protocol of cares. Findings were in congruent with Broom (1996) ${ }^{(33)}$ who found that the current study presents that there was been a significant decrease in relation of knowledge for 3 months after the protocol of care. This research worked and suggesting that retention of skills and knowledge quickly deteriorates with time if they were not used or updated regularly. Some refreshment courses were recommended on a regular basis. In this regard, Abd-Alla ${ }^{(36)}$ and Mehany (2000) ${ }^{(37)}$ who were in agreement with this result found a direct relation between memory and loss of length of time that relapses after a certain educational event.

The current study revealed that studied nurses' knowledge in relation to blood transfusion improved after the nursingcare protocol more than before. Blood transfusion reduces the side effects of low hemoglobin level which results from irregular treatment. If the child is not regularly transfused, he will show signs of jaundice, pallor and hemosiderosis. This is in agreement with Fathalla (1996) (38), who stated that the course of the disease in childhood depends almost on the regular blood transfusion according to the protocol of care. This result in the same line with Nabavizadeh (2007) ${ }^{(39)}$ who found that if thalassemia not treated properly, growth failure is one of the most important complications. This study was designed to evaluate the growth parameters in thalassemic children and compare the obtained data with normal children. Crosssectional, descriptive, and analytical study was carried out on 121 thalassemic patients who received blood transfusion therapy in Yasuj with respect to the physical growth considering the growth retardation of thalassemic patients; recommended regular intervals of blood transfusion.

The present study revealed more than half of the studied nurses' knowledge was correct but incomplete about thalassemic children foods which are rich in iron but their knowledge of foods which decrease or increase the absorption of iron was unsatisfactory. This knowledge was 
improved after the nursing-care protocol.

Nutrition in childhood especially has an important impact on health. The maintenance of proper nutrition is especially challenging for establishing good health and preventing some common nutritional problems and chronic disorders. Nutritional practices should be demonstrated to contribute to physical, emotional wellbeing, cognitive development as well as a long healthy life. Children should avoid food rich in iron and drink a cup of tea with every meal because it interferes with iron absorption in the diet. Children should avoid food rich in vitamin- $\mathrm{C}$ with meal times. These results are in agreement with El-Awany (2002) ${ }^{(40)}$ who mentioned that a quarter of children took food rich in iron or food or drinks that increase the absorption of iron as vitamin-C for minority of children.

Regarding growth, it can be an extremely complex process from infancy through adolescence. The assessment of nutrition and growth state is thus an important and integral part of care of the pediatric population. Regular assessment of nutrition can help identify infants and children at risk of malnutrition and thereby allowing nutritional intervention take place. Accurate measurement with the proper equipment and plotting of growth charts are the best approach to determine and classify the nutritional state of infants, children and adolescents.

This study reflected that about two thirds of the studied children were under weight and short stature for age and sex before the nursing-care protocol while there were improvements after the nursing-care protocol. This result related to lack of knowledge about food needs and allowance according to the child's developmental stage, health state and groups of alternatives according to socioeconomic status of the family. Normal weight is defined as a term used to describe weight ranges based on height that are satisfactory related to good health. If weight is lower or higher than these ranges, it increase the health problem normal weight for an individual may differ from normal to another individual. ${ }^{(39}$ ) Gronder (2005) ${ }^{(41)}$ mentioned that body weight is one of the most important measurements in assessing the nutritional state and used to periodic energy expenditure. Improvement of knowledge regarding thalassemic children's foods caused improvement in anthropometric measurement especially of child's weight. This result was in congruent with AlAwany (2002) (40) who studied the nutrition of thalassemic children and found 
that some improvement in the weight gained and slight increase in height after the program implementation. Khamis (2015) $^{(42)}$ who was also in agreement with this result found that more than a half of the studied thalassemic children were underweight while the rest of children who delayed their linear growth and also height for age was significantly correlated with weight for age, so the children were more stunted than wasted. The results of this study also in agreement according to statistical analysis of Nabavizadeh (2007) (39) who found that, the weight of $53.7 \%$ of thalassemic and $17.1 \%$ of non-thalassemic patients, with the same age group, was under the 5 th percentile $(\mathrm{P}<0.0001)$ and height were 66.9 vs. $17.1 \%$ under the 5 th percentile.

Regarding mid arm circumference and skin fold thickness, more than half of studied children were under normal standard of age and sex. Small changes were noticed before, immediately after and 3 months after the nursing-care protocol. This result was attributed to the short period of intervals between anthropometrics measurements and Lack of continuous nutritional education of both the thalassemic child and his/her caregiver regarding foods or drinks that contain iron. Nutritional deficiency which reflects on the child's growth was related to many factors: hospital, staff and patient. The factors related to hospital include the governmental hospital with limited budget, absence of qualified dietitian and there is no nutritional assessment tool or nutritional support protocol for the child. In addition, the factors related to staff included: the physician-prescribed nutrition in terms of volume to be, administered not in terms of actual calories needed and lack of nutritional knowledge. The factors related to child included: catabolic state accompanied the children's disease, surgery and low socioeconomic state. The results of this

study were in agreement according to statistical analysis of Nabavizadeh (20007) ${ }^{(39)}$ the mid-arm circumference was of $72.7 \%$ of thalassemic and $32.5 \%$ of non-thalassemic patients, with the same age group, was under the $5^{\text {th }}$ percentile.

Regarding the results of the current study which is in the same line with George (1997) ${ }^{(43)}$ who found that various growth parameters of 233 (140 boys, 93 girls) thalassemic children were compared with 74 (45 boys and 29 girls) non-thalassemic siblings. Weight and height were retarded in thalassemic children. The difference between thalassemic and non-thalassemic siblings was evident from 9+ years in both 
boys and girls. Growth parameters seemed to be adversely affected with the advancing age. Among head, chest and mid arm circumferences, the mid arm circumference was more affected than head and chest circumferences. Height and weight were more severely retarded in children with hemoglobin levels of less than $8 \mathrm{gm} / \mathrm{dl}$. The findings seemed to suggest that press of retardation was probably secondary to chronic hypoxia and iron overload.

\section{Conclusion}

Based on the findings of the present study, we can be concluded that there were lack of essential and proper knowledge and performance concerning thalassemic children management and education. The application of nursing care protocol led to improve in nurses' knowledge of thalassemia, blood transfusion, chelation therapy, splenectomy and anthropometric measurements. Performance also improved regarding blood transfusion and Desferal administration. This improvement didn't show the same extent 3 months after the nursing-care protocol. The clinical outcomes of thalassemic children improved and presented in the improvement of the children's anthropometric measurements.

\section{Recommendations}

Based on the present study, the following recommendations are

\section{suggested:}

1- The education should be provided through mass media to increase the consciousness of the public regarding the importance of the premarital counseling.

2- Screening of all newborn as much as possible to know the most common hereditary diseases.

3- Governmental plan for the prevention of thalassemia must be made all over Egypt. This will help decrease the incidence with the diseases of thalassemia in Egypt.

4-Bank of umbilical cord blood is a new trend that can help in the treatment of thalassemia especially among siblings. It is important to construct a special unit with well-trained personnel in the Hematology and Oncology Unit.

5- All nurses should be involved in periodic health-education programs.

6- Periodic meetings should be held with the nurses to know the points of defect and plans of teaching. 


\section{References:}

1-Rosdahl C. Text Book of Basic Nursing, 8thed. Philadelphia: Lippincott Williams Co., 2002; 234- 42.

2-Jane A. Primary Health Care of Infants, Children \& Adolescents, 2nd ed. St Louis: Mosby Co., 2002; 471- 79.

3-Leenstra T, Kariuki S, Kurtis D, Oloo A, Kager P, Kuile F. Prevalence and severity of anemia and iron deficiency: cross-sectional studies in adolescent schoolgirls in western kenya. European Journal of Clinical Nutrition 2004; 58 (7): 681-91.

4- El-Beshlawy A, Mostafa A, Inati A, Rashidy Y. International thalassemia day 4th international conference of thalassemia prevention and cure, Cairo: 2003; 60- 1 .

5-Vichinsky P, Neufeld S. Cooley's Anemia Ninth Symposium. 2010 Annals of the New York Academy of Sciences.

6-Staff member of pediatric department.

Pediatrics: Hematological and Oncology Disorders, 4th ed. Tanta University 2009; 329- 35.

7- Forget B, Cannelos N, Berlin E. Pediatric Clinics of North America. Thalassemia, St. Louis: Mosby Co., 2010; 24-6.
8- Origa R, Quarta G, Forni G, Longo F, Melpignano A, Galanello R. Pregnancy and beta-thalassemia: an Italian multicenter experience. Hematological 2010; 95(1): 376-81.

9- Ludder P, Vessey J. Child with a Chronic Condition, 2nd ed. Boston: Mosby Co., 2000; 405 - 17.

10-Nielsen $\mathrm{T}, \quad$ Bender $\mathrm{A}$. Hemoglobinopathies, In: Pediatric critical care, 4th ed. Bradley P. Fuhrman and Jerry Journal. Zimmerman. Elsevier Press 2011; 84(1): 1206-1191.

11-Abo-Elyazed D. Visual and auditory assessment in Egyptian thalassemic children with long-term use of desferroixamine, Unpublished Master Thesis. Tanta University, Faculty of Medicine 2004; 8-70.

12- Booker C, Nico M. Alexander's Nursing Pediatric, 4thed. London New York Co., 2011; 387-383.

13-Thomas B, Kate L, Halsted H, Kevin G. Patient self-management of chronic disease in primary Care, Journal 2002; 288(19): 2469-75.

14-U.S. Department of Health and Human Services, National Institute of Health, The management of sickle cell disease 2002; NIH publication.020117.Available at: www.nhlbi.nih 
.gov/health/prof/blood/sickle/sc_mngt.p df.

15- Jelliffe D. Assessment of the nutritional status of the community WHO. Geneva, 1966; 140-133.

16-World Health Organization (WHO), Anthropometric Indicators, Nutrition Unit, Division of Family Health, Geneva 1998.

17- Laeau S, Vandjick D, Rello J, Rosa A, Blot s. For the evidence study investigators, centers for disease control and prevention guidelines for preventing central venous catheterrelated infection: results of a knowledge test among European intensive care nurses, Journal of critical care medicine 2009; 37(1)323-320.

18- Ahmed R. Developing post-operative care standards for patients who had drainage of chronic subdural hematoma, unpublished Master Degree Thesis, Faculty of Nursing, Assuit University 2012;121.

19-Hussain M, Lyneham J. Cardiopulmonary resuscitation knowledge among nurses who work in Bahrain, international Journal of nursing practice 2009; 15(4):302-294.

20-Parajulee S, Selvaraj V. Knowledge of nurses towards cardiopulmonary resuscitation in a tertiary care teaching hospital in Nepal, Journal clinical and diagnostic research 2011; 5(8): 15881585.

21-Soliman O,Yahia S, Shouma A. Reverse hybridization strip assay detection of $B$ thalassemia mutations in northeast Egypt, Hematological 2010;15(3):182-6.

22- Bassit H. Golden 6 of $\beta$ globin gene mutation in correlation with phenotyping, clinical and dermatogyphic features in Egyptian children with $B$ - thalassemia, Unpublished Master Thesis, Faculty of Medicine Sohag Univerisity2014;85.

23- Temtamy S, Sobh A, El-Kamah Y. Investigating interfamilial phenotypic variability among Egyptian families of beta thalassemia cases: impact of genetic counseling, Journal app sci res 2009; 5(9):1189-1185.

24- Galanello M, Origa R. Beta thalassemia, Orephanet Journal of rare diseases 2010; 10(1): 1172-1750.

25-EL-Ghlban F. Assessment of nurses' knowledge and practice related to nosocomial pneumonia at Mansoura university children hospital, unpublished Master Thesis. Faculty of Nursing, Ain Shams University 2010; 34-133. 
26-Abo-Salem L. Self-care program for children suffering from beta thalassemia major, unpublished Doctoral thesis, higher Institute of Nursing. Alexandrea University 1999; $55-1$.

27-Mater T. Lifestyle profile of children with B-thalassemia major, unpublished Master Thesis. Faculty of Nursing, Tanta University, Egypt 2006; 103.

28-Porter B. Concepts and goals in the management of transfusional iron overload, Am journal haematological 2007; 82(12): 1139-1136.

29-Miskin H, Yaniv I, Berant M. Reversal cardiac complications in thalassemia major by long term intermittent daily intensive iron chelation, Eur Journal hematological 2003;70(6):408-398.

30-Taha O. Comparative study of efficacy of different iron chelating agents in treatment of iron overload in children with beta thalassemia major, unpublished Master Thesis, Faculty of Medicine Tanta university 2013;95.

31- Gomber S, Saxena R, Madan N. Comparative efficacy of desferrioxmine, deferiprone and in compination on iron chelation in thalassemic children, Indian pediatr 2004; 41(1):27-21.
32- Madden C. Understanding nursing student's acquisition and retention of CPR knowledge and skills, nursing education today 2006; 26(2):218-27.

33- Broom R. A quasi-experimental research to investigate the retention of basic cardiopulmonary resuscitation skills and knowledge by qualified nurses following a course in professional development, Journal of nursing 1996; 23(1): 1023- 1016.

34-Inwood H. Knowledge of resuscitation, intensive care and critical care nursing 1996; 12 (1):39-33.

35-Moule P, Knight C. Emergency, cardiac arrest, can we teach the skills? Nurse education today 1997; 110-99.

36-Abd-Alla M. Assessing quality care through a managerial in service training program for head nurses working in Assuit university hospital, DNS thesis of nursing service administration Assuit university 2000;22.

37-Mehany M. Effect of nursing care program on emergency nurses performance, DNS thesis in medical surgical nursing. Assuit university 2000; 166(1):167.

38-Fathalla M. Platelet aggregation and natural coagulation inhibitors in 
splenectomized and non-

splenectomized thalassemia children, unpublished Master Thesis. Faculty of Medicine, Tanta University, Egypt 1996; 8-5.

39- Nabavizadeh S, Anushiravani A, Haghbin S. Evaluation of growth parameters in patients with thalassemia major, hematology 2007; 12(5):445-7.

40-El-Awany S. Nutritional program for children with Beta thalassemia major and their mothers, Unpublished Doctoral Thesis, Higher institute of Nursing Tanta University 2002;50-1.

41- Gronder M, Anderson S. Foundation and Clinical Application of Nutrition, Nursing Approach, Mosby Boston Co., 2005; 363-72.

42- Khamis R. IVSII-848 gene of Bthalassemia in Egyptian children correlation with phenotyping, clinical and dermatoglyphic features 2015; unpublished Master Thesis, Faculty of Medicine Tanta University 2015; 103. 43- GeorgeA, Bhaduri A, Sen S, Choudhry P. Physical growth parameters in thalassemic children, Indian Journal Pediatr 1997; 64(6):861-71. 